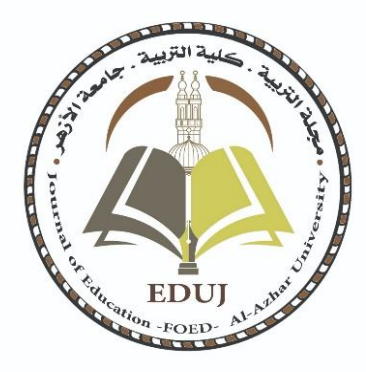

\title{
دور جامعة أم القرى في تنمية قيم العمل التطوحي لدى طالباتها
}

\author{
إعداد \\ د/ فمرية بنت مممد إسماعيل خوه \\ أستاذ مشارك التزبية الإسلاهية، قسم التربية الإسلامية والمقارنة، كلية \\ التزبية، جامعة أم القرى البرى
}




\section{دور جامعة أم القرى هِّ تنمية قيم العمل}

\section{التطوعي للدى طالباتها}

فخرية بنت محمد إسماعيل خوج. قسم التربية الإسلامية والمقارنة، كلية التربية، جامعة أم القرى. dr.f.khoj@hotmail.com :البريد الالكتروني المستخلص:

هدفت الدراسة إلى الكثف عن صعوبات دور جامعة أم القرى ِِّ تنمية قيم العهل التطوعي لدى طالباتها، والكشف عن سُبل التغلب على تلك الصعوبات مـن وجهة نظر طالباتها .ولتحقيق هذين الهدفين اتبعت الدراسـة منهجيـة البحـث الوصفي التحليلي

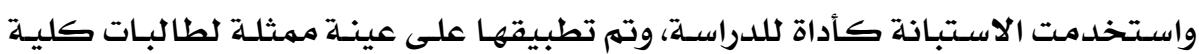
التربيـة بجامعـة أم القـرى مكونـة مـن (380 طالبـة) مـن المجتهـع الأصل، وقد تم تفسير

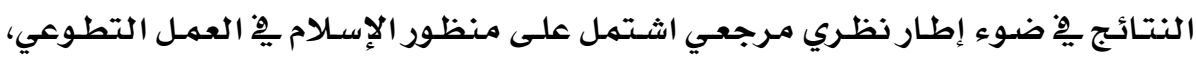

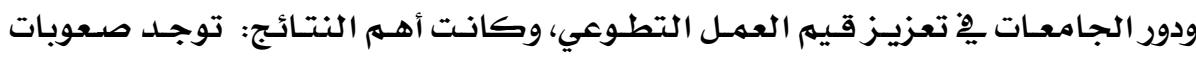

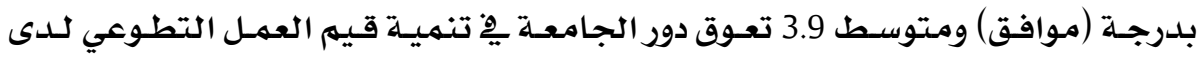

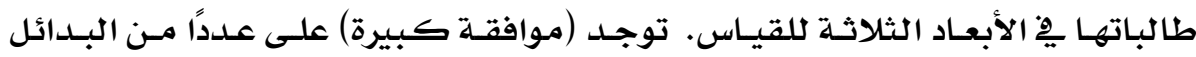

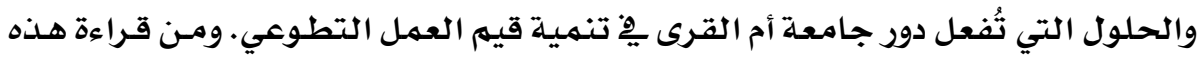

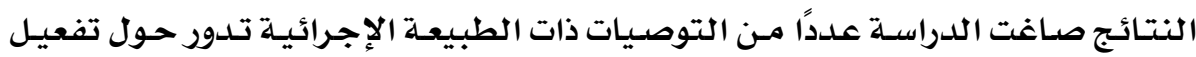
دور جامعة أم القرى يِّ تعزيز قيم العمل التطوعي لدى طالباتها. الكلمات المفتاحية: التطوع، العمل التطوعي، قيم العمل التطوعي، طالبات الجامعة. 
The Role of Umm Al-Qura University in Developing the Values of Fakhriya Bint Mohammed Khoj Voluntary Work among Female Students

Islamic and Comparative Education Department, Faculty of Education, Umm Al-Qura University.

Email: dr.f.khoj@hotmail.com

\section{ABSTRACT}

The study aimed to identify the difficulties of achieving the role of Umm Al Qura University in developing the values of voluntary work among female students, and to determine ways to overcome such difficulties from the viewpoints of Umm Al Qura University female students. To meet these two ends, the study adopted the descriptive analytical method making use of a questionnaire as an instrument which was conducted to (380) female students at the Faculty of Education, Umm Al-Qura University. The results were discussed in the light of the theoretical background that included the Islam perspectives of voluntary work, and the role of universities in enhancing the Isamic values. The most important results attained revealed that there where some difficulties with an average degree as the mean score was 3.9 which hinders the university from achieving the role of developing the values of voluntary work among students in the three dimensions of measurement. There were (strong agreement) on a number of alternatives and solutions that may activate the role of Umm Al-Qura University in developing the values of volunteering. In the light of the above results, the study presented a number of procedural recommendations which aimed at activating the role of Umm Al-Qura University in strengthen the values of voluntary work among female students.

Keywords: Volunteering, Voluntary Work, Values of Voluntary Work, Female University Students. 
يُعـد العهـل التطـوعي قيهـة عظهى مـن قيهم الإسـلام الأسـاسيـة، التي حـث عليها

الشرع الحنيف وندب اليها .وشثار العمل التطوعي وعائده عظيهم على الفـرد والمجتهـع...

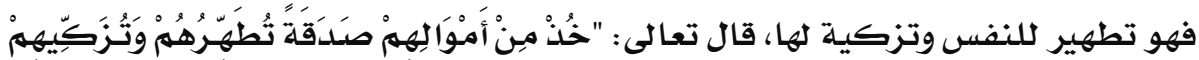

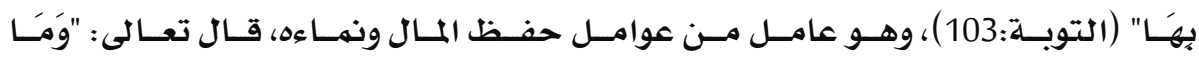

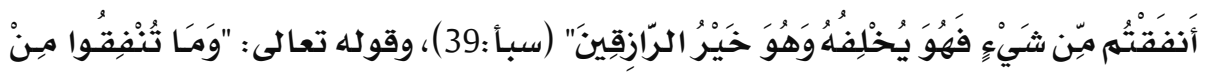

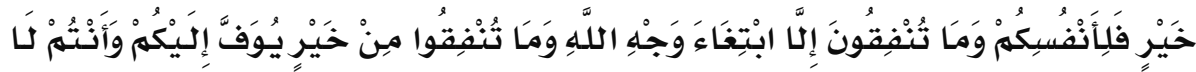

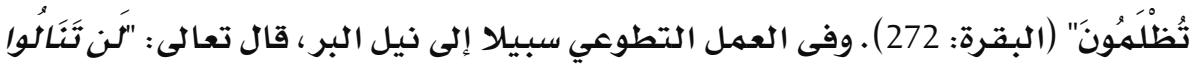

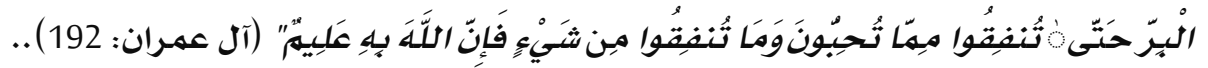

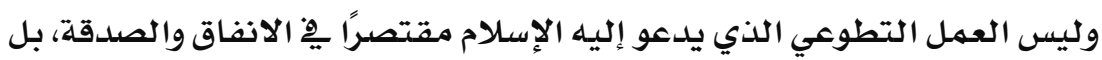
ثهـة صور وأشكال متعددة أوضحتها الأحاديث النبويـة، ووجـدت تطبيـق لـى المعلم الأول

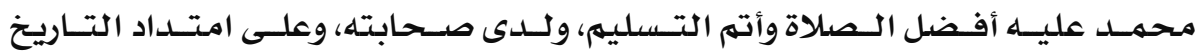
الإسـلامي، ويكفى أن الرسول قد عُد العمل التطوعي يِّهورة إماطلة الأذى عن الطريـق

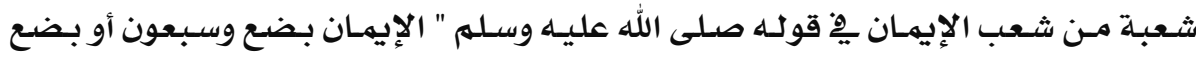
وستون شعبه فأفضلها قول لا إله إلا الله وأدناها إماطة الأذى عن الطريق والحيـاء شعبـة من الإيمان" رواه مسلهم.

والعمل التطوعي يِ المملكة العربية السعودية ومنــ توحيد الدولـة السعودية قـد وجــ اهتمـامـًا كـبيراً مـن جانـب أولـي الأمـر، وكثـرة مـن العلمـاء والمفكـرين وأصسحاب الأعمـال والموسـرين. ومـن العلامـات علـى اهتهـام الدولــة السعودية بـالعمـل التطـوعي، صدور لائحة الجمعيات والمؤسسات الخيرية بقرار مجلس الوزراء يف 1410/06/25هـ ( 1 (1)

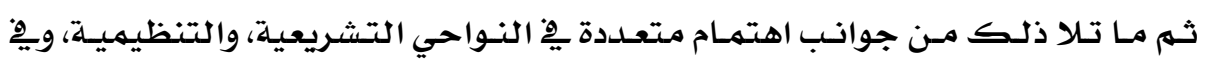
مجال الدعوة والفكر المرتبط بـالعمل التطوعي، والذي أصبيح مكونا رئيسيا مـن مكونات الثقافة السعودية الحاضرة.. وكان صدور مشروع "نظام العمل التطوعي"، والذي اعُد بناء على المادة (23) مـن

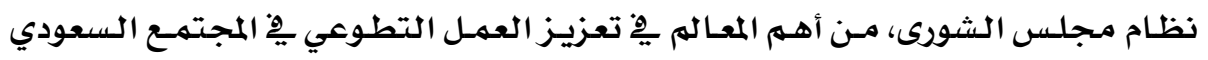

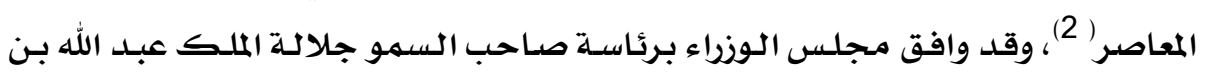

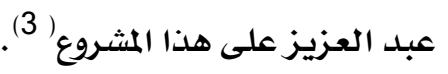




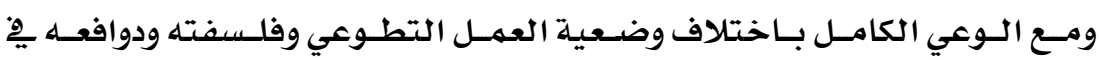

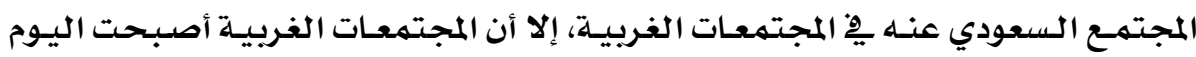

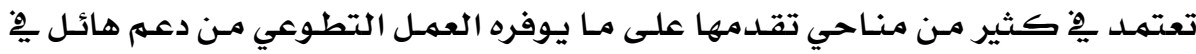

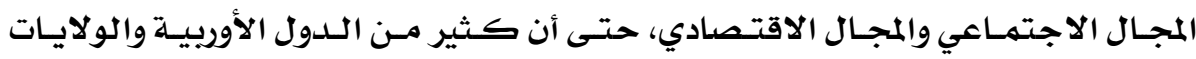

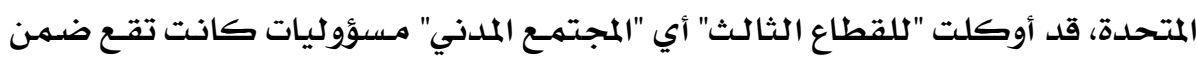

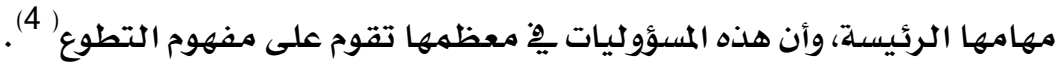
وإدراكًا من الدولة السعودية لقيمة العمل التطوعي يِّ تربية شخصيات الأفراد،

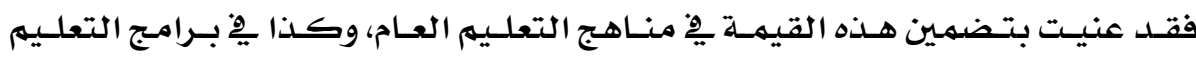
الجامعي، ويستدل على هذا الاهتمام من إصدار اللائحة التنظيمية للعمل التطوعي فِ

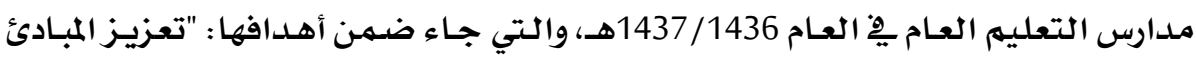

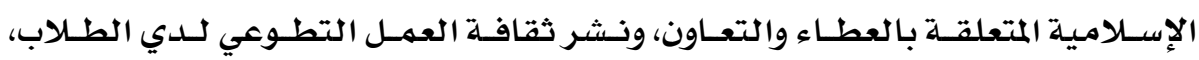

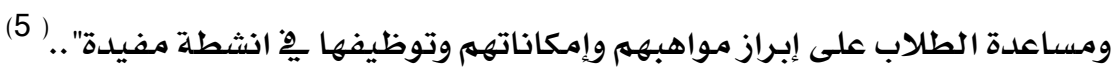
كـذلك احتلـت جامعـلة أم القـرى - وهـي محسل تركيـز الدراســة- مكانـة

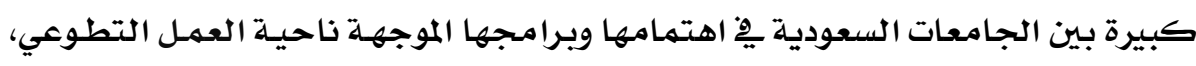

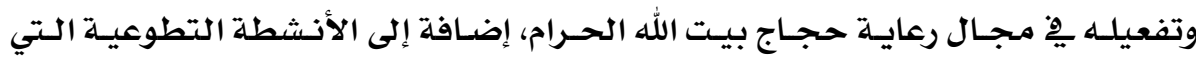

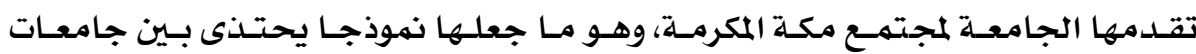
المملكة، والجامعات الإسلامية بوجه عام. 


\section{القسم الأول: إطار الدراسة}

\section{موضوع وهدف الدراسة:}

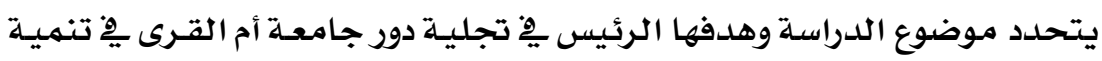
قيهم العمل التطوعي لدى طالبـاتها، وهـو الدور الذي ينطلـق مـن رؤيسة ورسـالة الجامعـة

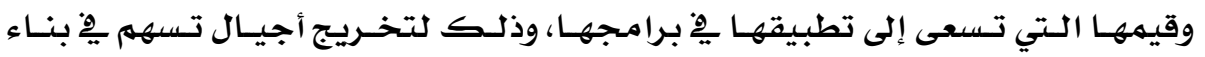
مجتمعها، وتعُين على تنفيذ رسالة الإسلام ِِِ أقدس بقاع الأرض. وعلـى الـرغم مـن تعظـيم الإســلام للعمـل التطــوعي، وإيـلاء الدولــة الـسعودية

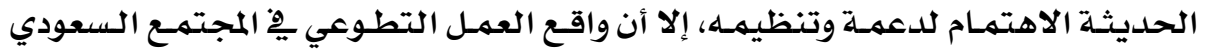
ينبئ عن نوعا من التقصير، ٌِِ هذا الباب من أبواب الخير، وكها تشير الشواهد ونتائج بعـض الدراسـات الحديثـة (6) إلى عـدد مـن الـصعوبات، منهـا مـا يتعلـق بـنقص ثقافـة العمل التطوعي، وافتقاد التنظيهم والتخطيط، ونقص يِّ التـدريب للقيـادات والقـائمـين على إدارة هذا العمل، وفى أحيان أخـرى نقص أو غمـوض يِّ اللـوائح والتشريعات المعنيـة

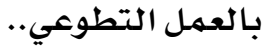

هذا ويبرز واقـع العمل التطوعي يِّ المملكـة قصورًا يِّا اعداد المتطوعين وإحجـاب الشباب الجامعي بوجه خاص عن الانخراط يِّ المبادرات والبر امـج التي تتيحها الجامعـة،

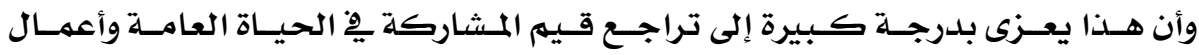

(7). التطوع

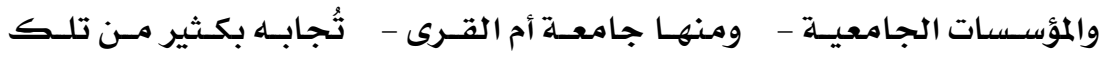
الصعوبات يِ عملها، وبخاصلة فيما يتعلق بضعف ثقافة العمل التطوعي لدى طالبـاتها، وهـو مـا يعـني ضـرورة بـذل جهـد أكبر مِّعزيـز هـذه الثقافـة، والعهـل العلمهي المخطط لتنميـة قيهم العمل التطوعي لدى الطالبات. ومن هنا تبرز أسئلة الدراسية، وهي:

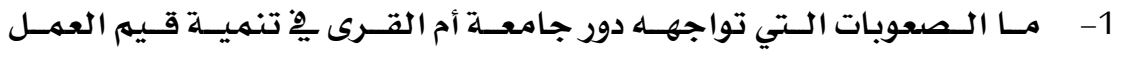
التطوعي لدى الطالبات.

2- وما وجهة نظر الطالبـات ِِِ تعزيز هذا الدور الذي تضطلع بـه الجامعة؟ 


$$
\begin{aligned}
& \text { جامعة الأزهر } \\
& \text { كلية التربية بالقاهرة العدد: ( 189)، الجزء (الثاني)، يناير لسنة 2021م } \\
& \text { مجلة التزبية }
\end{aligned}
$$

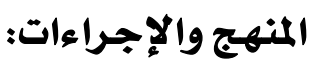

تتبـع الدراسـة أسـلوب المـنهج الوصـفي، وتستـخدم الاسـتبانة لمناسـبتها موضـوع

$$
\text { الدراسة، وذلك كما يلي: }
$$

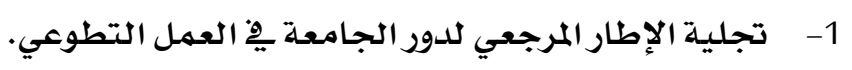

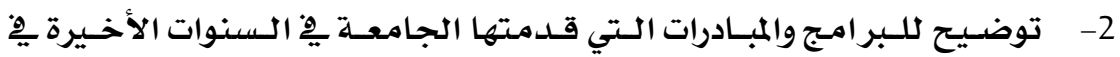

مجال العمل التطوعي، والصعوبات التي واجهتها.

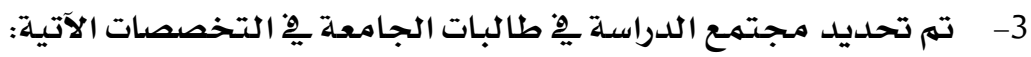

$$
\text { أ- العلوم الشرعية (1295 طالبه). }
$$

$$
\text { ج- العلوم الاجتماعية والتربوية (5978 طالبه). }
$$

4- تم اختيار عينه ممثلة لهذه التخصصات بلغ عددها 380 طالبـه مـن مجتمـع

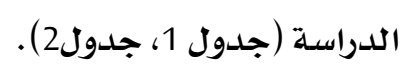

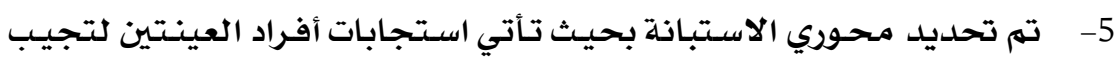

$$
\text { عن الأسئلة البحثية، وهما: }
$$

المحور الأول: صعوبات دور الجامعة يِّ تنمية قيم العهمل التطوعي.

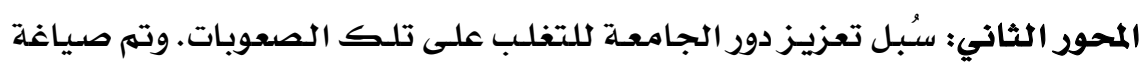

فقرات كل محور، وتحديد أسلوب القياس لكل فقرة وفق مقياس

$$
\text { ليكرت الخماسي. }
$$

6- تم تفريغ استجابات أفراد العينـة مـن الاستبانة وتحليلها باسـتخدام برنامـج

$$
\text { .SPSS }
$$

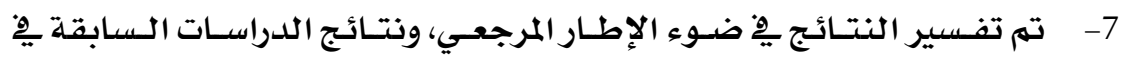

$$
\text { مجال الموضوع. }
$$

$$
\text { 8- وتبع ذلك استخلاص توصيات الدراسلة. }
$$

نطاق وحدود الدراسة:

نظراً لاختلاف طبيعة وبرامج العمل التطوعي يِّ الجامعات السعودية، بـاختلاف

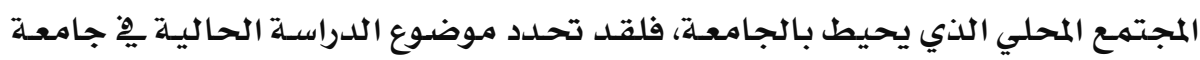




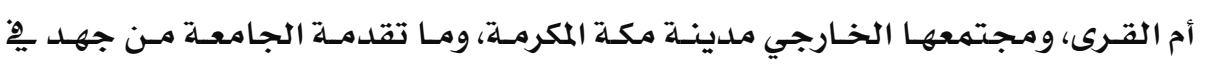
تزويد طالباتها بقيهم العمل التطوعي.

ولقد تحدد اهتمام الدراسلة وتركيزها على هذا الدور الذي تضطلع بـه الجامعـة،

وذلك كون الخطط والمبـادرات والهبر امـج التي تضعها الجامعـة لـن يكتب لها النجـاح مالم ترتكز على إطار قيمي للطالبـات يتضهن الاعتقاد ِِِ جدوى العمل التطوعي، وإنـه عمـلا يرضـى عنـه الله ورسـوله قبـل أن يكسون هـدفًا للجـامعـة ومـن هـذه القـيهم: الإيثاريـة، والتكافلية، البذل، نبذ التعصب، الرفق،...... | المصات:

يُعد "مصطلح "العمل التطوعي" مـن المفاهيهم التي تستغرق تخصصات عديدة يِ

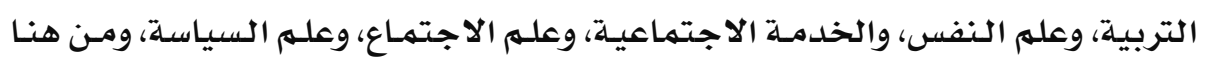
تعددت الأدبيات التي تدرس هذا المفهوم..

ومـن أهم التعـريفـات التي تنـاولـت مفهوم العمـل التطوعي، مـا أورده قـاموس علـم الاجتمـاع على أنـه: "وصف للطـرق النظاميـة الـتي تستعمل يخ تقـلديم العـون والمسـاعدة للهـحتــاجـين الـذين لا يـستطيعون التغلـب علـى المـشاكل والأزمـات الحياتيــة الــي (8). تواجههم بأنفسهمه ويعـرف "التطـوع"، علـى أنـه "الجهـد المبـذول الـذي يقـوم بـه فـرد أو مـجموعـة مـن الأفـراد بــافع الرغبـة ِِف عمـل الخـير دون الحصول على مقابـل أو توقـع الحصول عليـه،

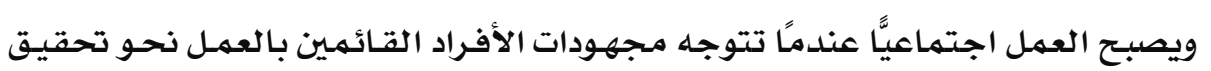
غايات تعود بالنفع على المجتهـع.(9) ويأتي الحرص على تعميق معنى ومفهوم العمل التطوعي، والتطوع لدى الشباب وأفراد المجتمـع بوجه عام من منطلق الأهميـة المتحققة من هـا المفهوم، والتي تتضـح فِ النقاط الآتية:. (10)

\section{1}

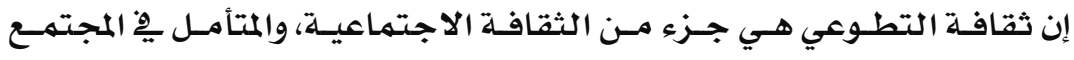
السعودي المعاصر، يجـدها تتكـون مـن الثقافة الإسـلاميـة المتراكمـة عبر عصور الإسـلام

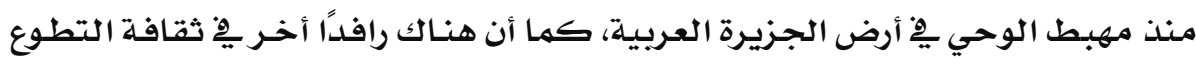
يِّ المجتمـع السعودي يـرتبط بـالعصر، وهو الذي يهكن النظر إيـه مـن منظور "المجتمـع 


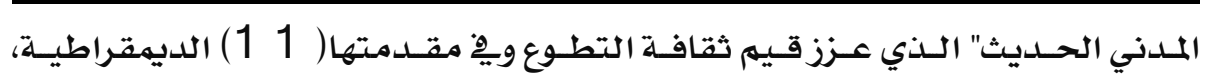
التسامح الفكري، القبول بالتعلد والاختلاف، المشاركة، احترام المواطنة، سادة القانون.

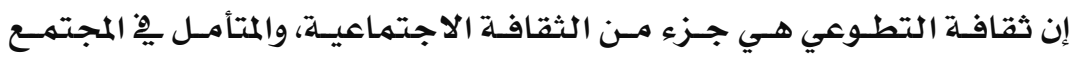
السعودي المعاصر، يجدها تتكون مـن الثقافة الإسـلامية المتراكمـة عبر عصور الإسـلام

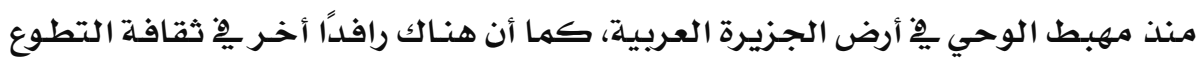

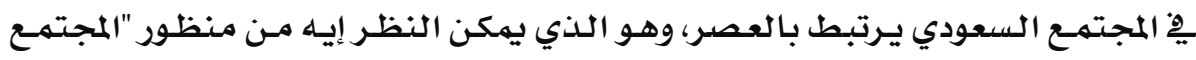

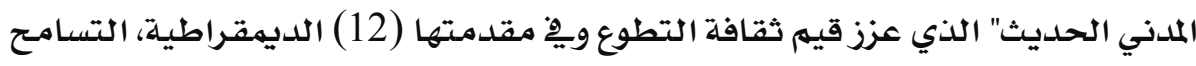
الفكري، القبول بالتعدد والاختلاف، المشاركة، احترام المواطنة، سادة القانون.

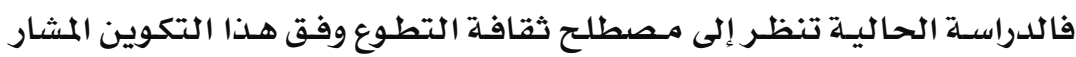

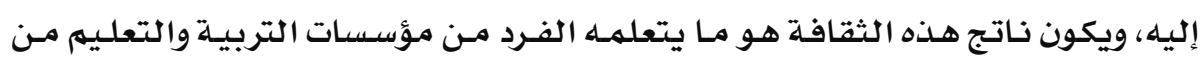

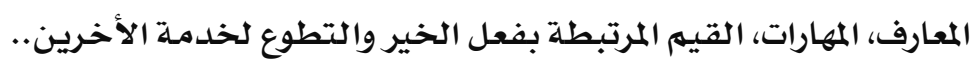

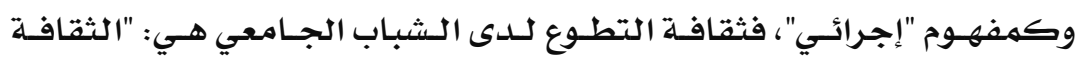

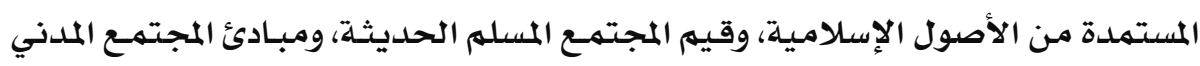

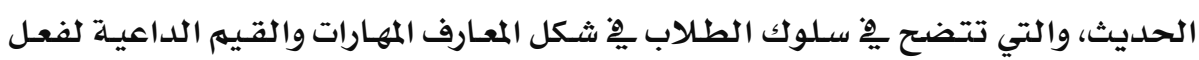

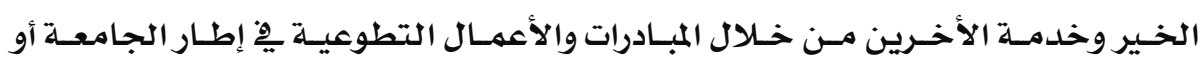

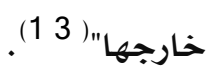

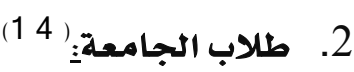

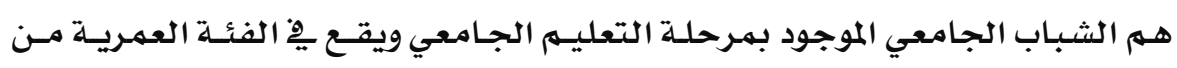

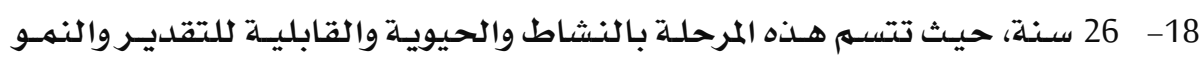
والقدرة على العطاء. وطلاب الجامعـة هـم الطـاب الذين يتلقون المعرفة والمحاضرات والتدريـب على كيفيـة

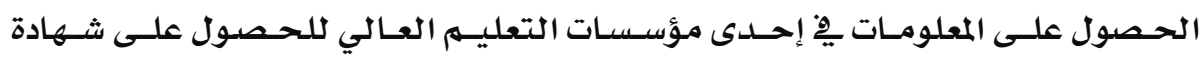

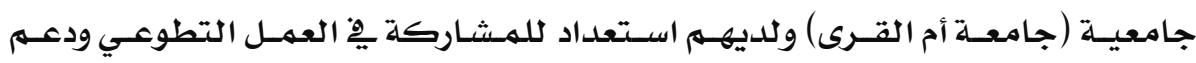

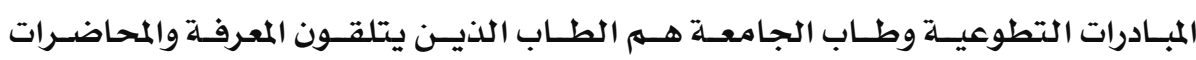

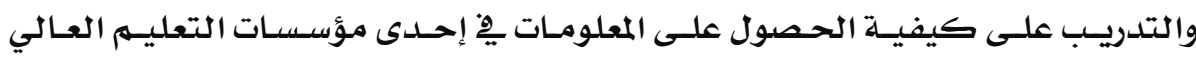

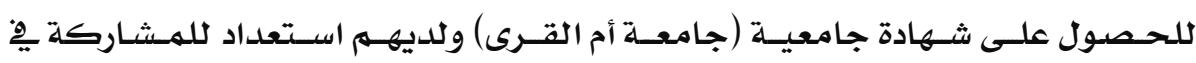


العهـل التطوعي ودعمى المبادرات التطوعيـة بـافـع مـن الانتماء والولاء لهذا المجتهـع دون

انتظـار أي مقابل نتيجـة لهذا العمل.

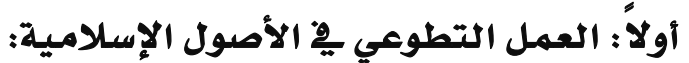

فقــ حفـل القـرآن الكـريهم والسنـة النبويـة المطهـرة بهعـاني ودلالات العمـل التطـوعي،

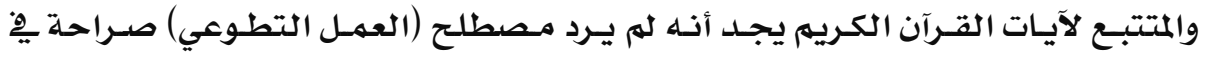

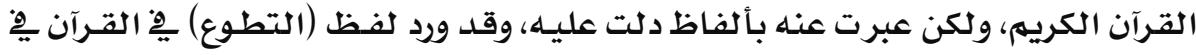

موضعـين:

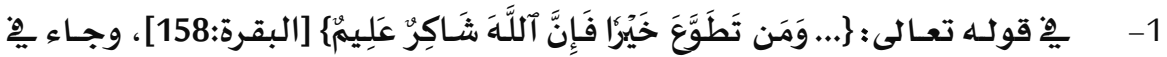

معنى هذه الآية "إن مـا يأتيـه المؤمسن بشيء مـن النوافل، فِإن الله يشكره، وثـكر الله

للعبد إثابته على طاعتهه"( 5 1).

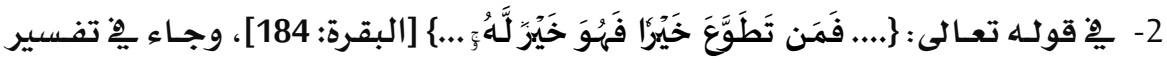

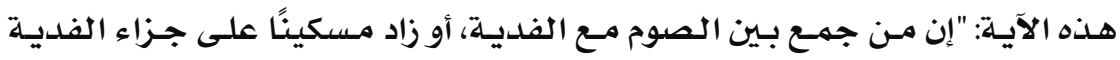

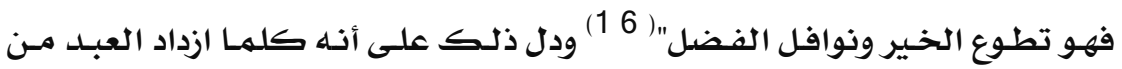

طاعة الله ازداد خيره وكماله، ودرجته عند الله، لزيادة إيهانه". ( 7 1)

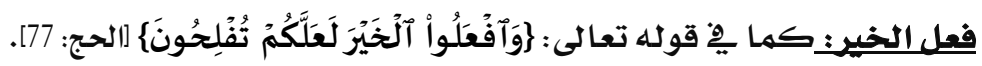

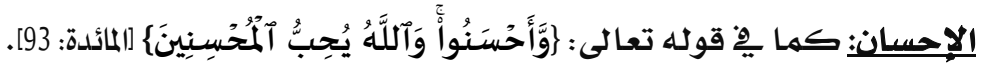

الإنفاقِ: كما ِِِ قوله تعالى:

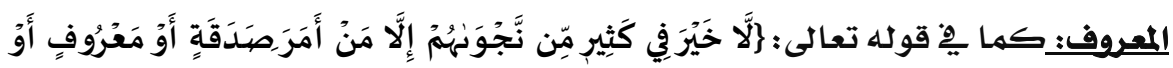

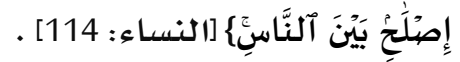

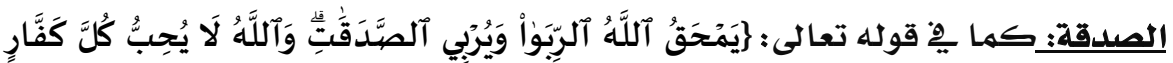

$$
\text { أَثِيمِ| [البقرة: 276] }
$$

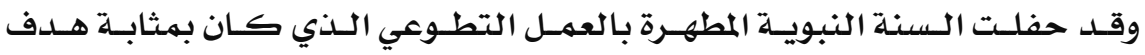

ومقصد الشريعة ولاستقامـة وسلامـة المجتمـع المسلهم ومـن نهـاذج الهدي النبـوي يِّ إعلاء

$$
\text { قيهم العمل التطوعي: }
$$

1- ذكر الفضائل والحزاء لـلأعمال التطوعيـة عند الله عز وحل:

يقول الحبيب صل الله عليه وسلك "المسلهم أخو المسلهم لا يظلمهـ ولا يسلمـه، ومـن كـان

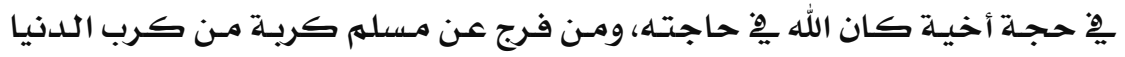


فـرج الله عنـه كريـة مـن كريـات يـوم القيامـة، ومـن سـتر مسـلهًا سـتره الله يـوم

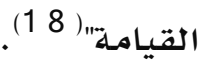

2- الرعايـة الاجتماعية لفئات المجتهـع:

فقد اهتم الرسول (صلى الله عليه وسـلم) فقال : "أنـا وكافل اليتيم كهاتين ِِّ الجنـة

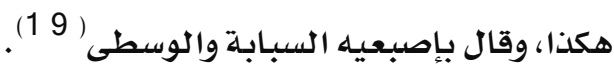

3- بناء المجتمع وتنميلة:

جاءت كثرة من الأحاديث النبوية التي تحثُ على بنـاء المجتهـع وتنميتهه، حـث الحبيب (صلى الله عليه وسلهم) على بناء المساجد ومن ذلك قوله : "من بنى مسجدًا

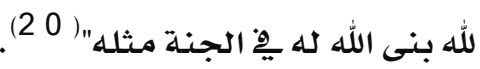
ومن الآيات الكريمات، ونماذج السنة النبوية المطهرة، تتضح فلسلفة الإسلام وغاياته مـن

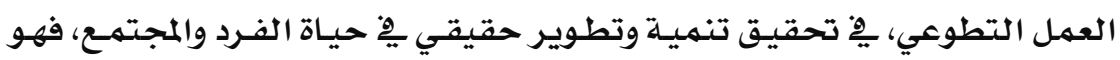
تطـوير للفـرد المتطـوع مـن حيـث تحقيـق الإثـبـاع الــاتي، وتنـميـة قدراتـه، ومـــه بروافد القيم الإنسانية الراقية. وهو تطوير للمجتمـع - أي العهـل التطوعي-

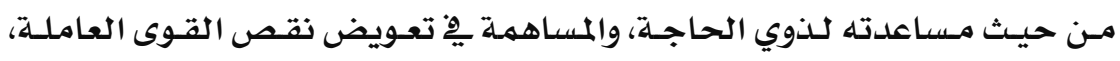

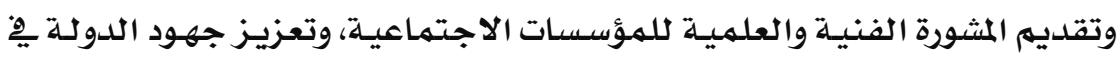

$$
\text { مواجهة المثكلات الاجتماعية ( } 1 \text { 2). }
$$

\section{ثانيًا : دور الجامعة مِّ تعزيز قيم العمل التطوعي:}

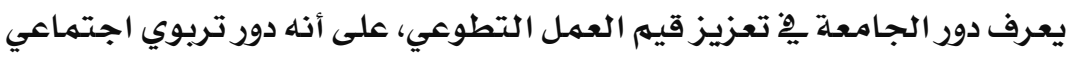
نفسي، تضطلع به الجامعات بِّ سياق وظيفة خدمـة البيئة والمجتمع بصفة أساسية

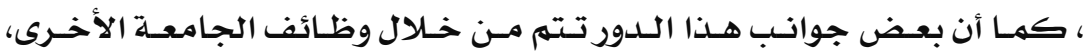

$$
\text { وظيفة التعليه/ التدريس ووظيفة البحث العلمي ( } 2 \text { 2). }
$$

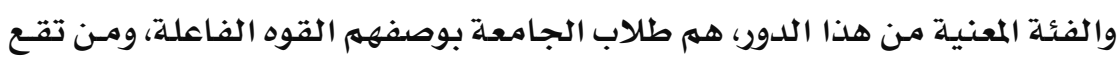
عليهـم مسئولية تنفيذ البر امجج والمبـادرات الخاصـة بالعمل التطوعي وهـم - أي طلاب

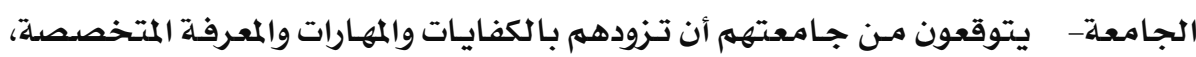

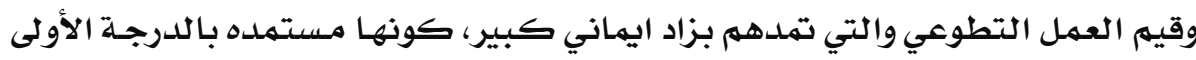

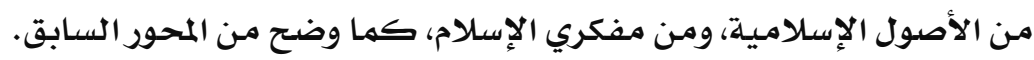




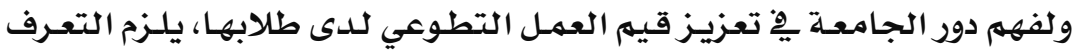

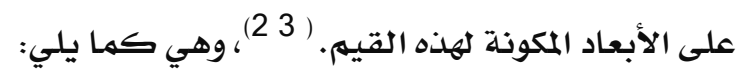

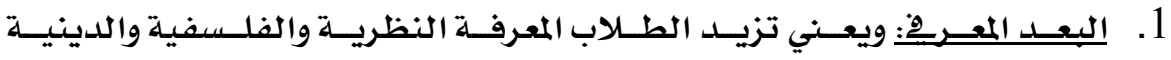
والاجتمـاعية والنفسية التي تتعلق بقيهم العمل الطالب.

2. البِعــــ الوحســاني:ويعـني ذلـك الارتبـاط العـاطفي والمكانـة الـتي يحتلـها العمـل

$$
\text { التطوعي ِِ قلب وعقل المتطوع. }
$$

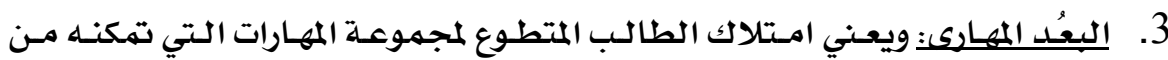

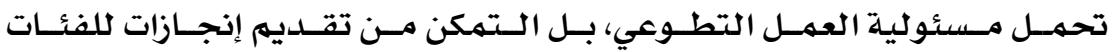
المستفيدة.

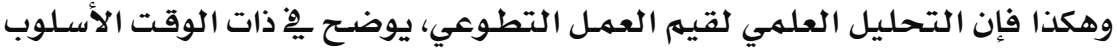
التربـوي الذني يهكن أن تتبعـهـ الجامعـة والمؤسسـات التربويـة عمومـا ِِِ اكسـاب طلابها للجوانب المعرفية والوجدانية والمهاريـة لهذه القيه، ومـن نهاذجها قيهم: الايثار، التكافل، التراحم، والتعاطف،....الخ. وهذه القيه وفق ما أشير إليه يمكن اكسـابها الطلاب يِّ سـياق البر امـ الدراسـيـة

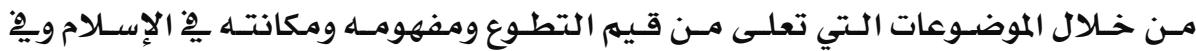

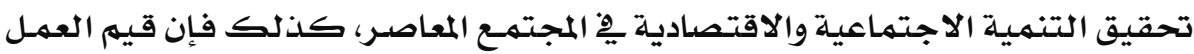

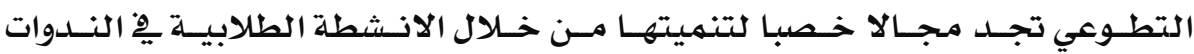
الثقافية، والأعمال الفنية، والأنشطة الإعلاميـة، وغيرها ..... ويِ سياق تعزيز قيم التطوع لدى طلاب الجامعـة، فثمـة طرائق وأسـاليب تربويـة متعددة تبرز لهذا الدور. 4 20

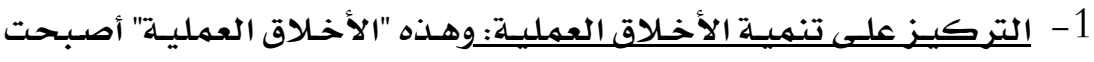
ضرورة لازمـة يِّ مواجهة مـا عـرف عن العهـل التطوعي الجـامعي مـن كونهـ موضـوعا نظريـا، وشـعارا يـتم ترديـده كـدليل على التعـاطف مـع مسككلات

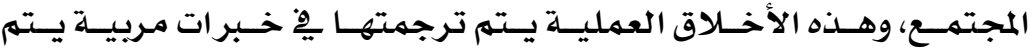
تصميمها وتخطيطها ِِِ برامـج جامعية متخصصدة.

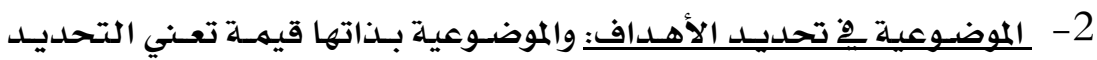

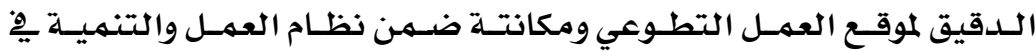


المجتمـع، وتعني أيضاً التحديد الدقيق للأهداف والعوائدس المتوقعـة، وتحضير الموارد والامكانات التي تُعين ِِّْ تحقيق هذه الأهداف.

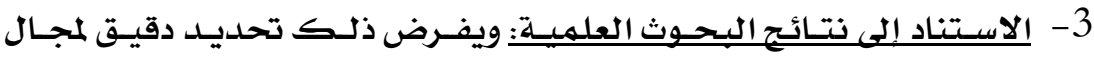

العمل التطوعي وأولوياتـه ومتطلباتـه، وهـذا يتطلب بـادئ ذي بـدء الاستنتاد

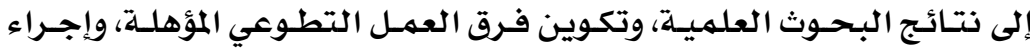

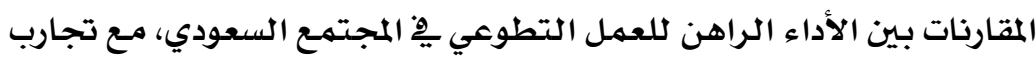

$$
\text { وخبرات الأخرين. }
$$

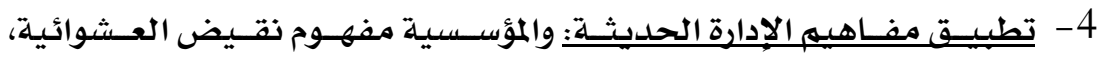
والفردانيـة، وهــي تتـضمن ِِِ طياتهـا تطبيـق مفــاهيم الإدارة الحديثــة:

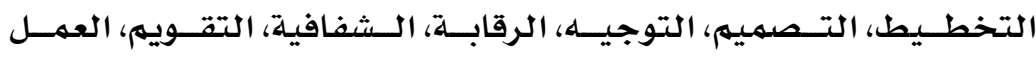

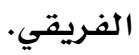

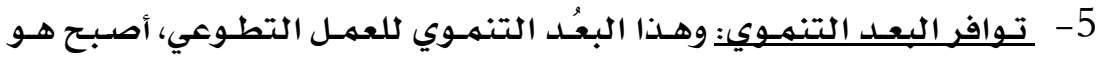

المفهوم السائد يِّ الدول المتقدمـة، وبخاصـة مـن حيث وضـع أهـداف وغايـات

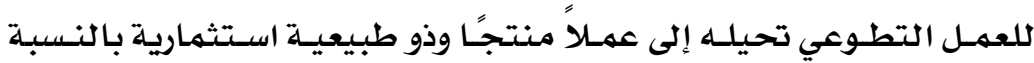

$$
\text { للفئات المستفيدة من العمل التطوعي. }
$$

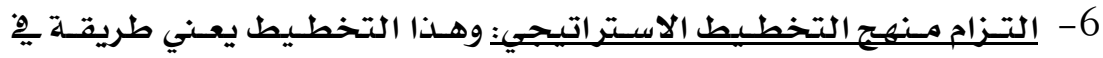
التفكير الذي يتبـع لتحقيق أهداف بعيدة الملدى، استنادا إلى تحليل علهـي

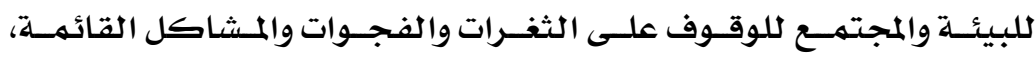
والتحول بها إلى فرص ومميزات، والاستفادة يِّ ذلك مـن التغذيـة الراجعـة أي نتائج التقويهم الذي يجري على العملى فرصل التطوعي. ثانثًا: نماذج العمل التطوعي يِّ الجامعات السعودية: ومما لاشك فيه أن العمل التطوعي فِ منظور الإسلام، وإن كان مسؤولية كل فرد

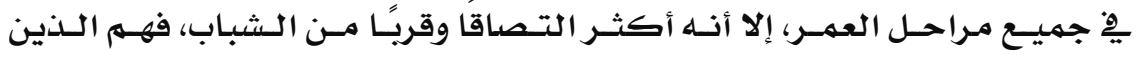
يتحملون القدر الأكبر من مسؤولياته، والتخطيط له، وتنفيذ مشروعاته، وثمسة دوافع

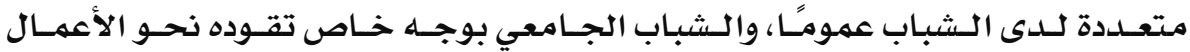

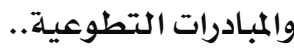


فإضافة إلى الدوافـع الدينية التي سبق بيانها انطلاقًا من توجيهات القـرآن الحنيـ،

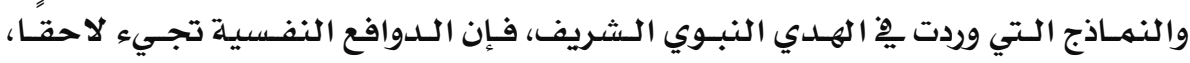
وأهمها أن هذه الأعمال تزيد من ثقة الشباب بنفسـه، وتحقق له الإثـباع، وتجعلـه أكثر احترامًا لذاته، وتشغل وقته بها ينفعهـ. هذا وتبرز الأدبيات( 5 2) نهاذج أخرى من دوافع الشبـاب للعمل التطوعي، اقتصادية، واجتماعية، وتريوية...

ومـن أبـرز مـا قدمتهه الجـامعـات السعودية، تبني (كراسي العهـل التطوعي)، ومنها : كرسي الأمير سلطان لدراسـات العهـل الخـيري التـابع لجامعـة الإمـام محمهد بـن سعود

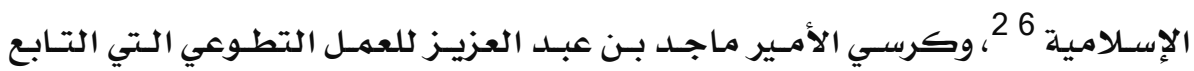

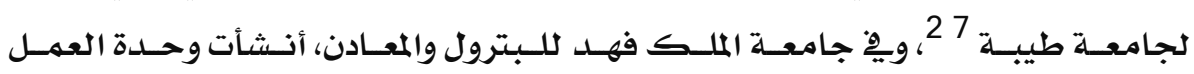
التطوعي ثمثل حلقـة وصلـل بـين الطلاب وبـين الجهات المجتمعيـة ذات الصلـة بـالتطوع، وكان من أبرز أعمال هذه الوحدة تبني نشر ثقافة التطوع لدى الشبـاب الجامعي، ولدى المحيط الاجتماعي ( 8 2. رابعًاً : نماذج العمل التطوعي يِّ جامعة أم القرى:

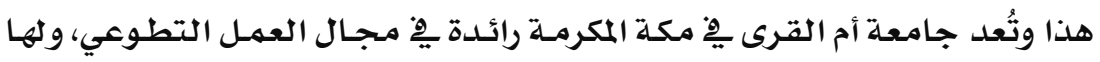

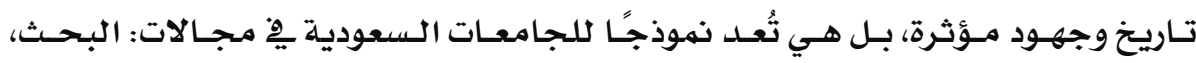
والتخطيط، والتنفيذ لكثرة من الأعمال والمبادرات، وكنماذج لها 9 2)؛ 1 - 1 الدراسـات والبحوث:

المؤتمـر العلمي الأول للخدمات التطوعيـة بالمملكة العربية السعوديـة، 1418 ندوة العهل التطوعي وأفاق المستقبل 1433/10/29هـ. الحارثي عبد الرحمن بن خضر، تصور مقترح لدور الأسرة ٍِِ اكساب قيم العمـل التطـوعي لـدى أبنائهـا مـن منظــور إسـلامي، مـاجستير، جـامعـة أم القرى، مكة المكرمـة، 1431هـ.

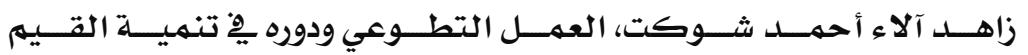
الاجتماعية لدى الشباب، ماجستير قسهم العقيدة، 1434هـ. 


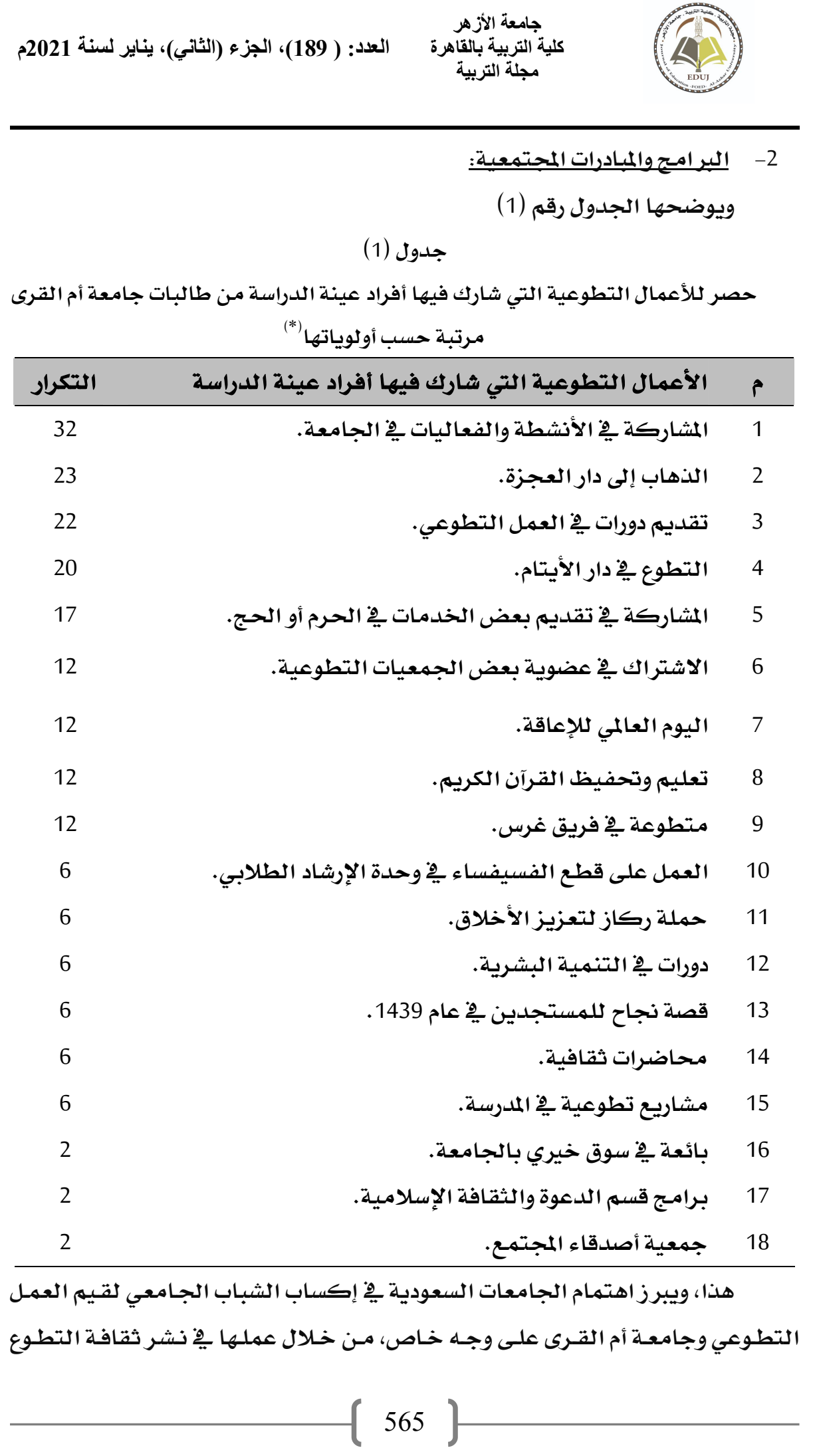


لـلى الشبـاب ولـدى المحيط الاجتمهاعي، وهـو اهتمـام نابع بالدرجـة الأولى مـن الثقافـة

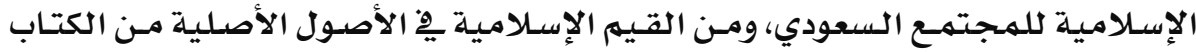
والسنـة كما أشـرنا يِّ السـابق.

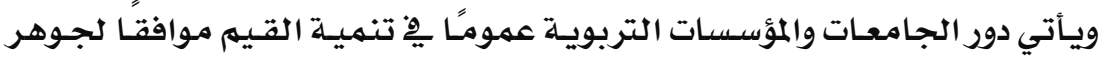
طبيعـة الإنسسان، ولطبيعـة القـيهم ذاتهـا فالأنسـان لديـهـ اسـتعداد فطـري كـامن لفهـم

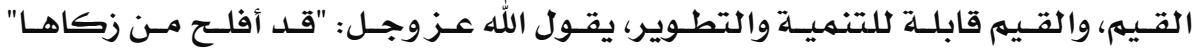
(الشـمس: 9)، وقيـل أيـضًا : "أن النـاس مطبوعـون علـى قبـول الحـق، وينتقلـون بالتأديـب

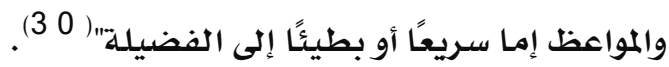

وثهـة صعوبات وتحديات تواجه دور الجامعات السعودية يْ عملها لتنهيـة قيهم العهـل التطوعي، وكنماذج لهذه الصعوبات ( 1 3) : أولا : صعويـات تعود إلى شخصيـة الطالب: وهـــه تتعلـق بـنقص ثقافـة الطالـب ووعيـه ومعـرفتـه بالعمـل التطــوعي وفلـسفته وقيمـة، وما يترتب على هذا من عدم تقديره لجدوى العمل التطوعي. ثانيًا: صعوبـات تعود إلى المنظومـة الجحامعيـة: وِِِ مقـدمتها صـوبـة تحقيـق التـوازن بـين العمـل التطـوعي وبـين الدراسـة، ونقـص

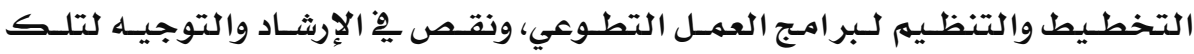
البر امـج من خلال الوظائف الجامعيـة. ثالثًا : صعوبـات تعود إلى المنظومـة المحتمعيـة:

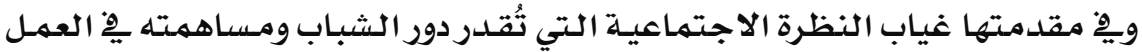
التطوعي، وغياب النظرة التي تقرن بـين العمل التطوعي وبـين تحقيـق إسهام يُعتدل بـه يِ

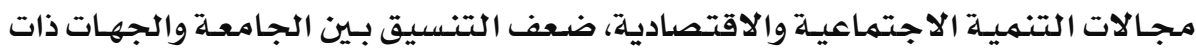
الصلة بالعمل التطوعي يِ المجتمع الخارجي... 


$$
\text { كلية التزربية الألقاهرة: العداد: ( 189)، الجزء (الثناني)، يناير لسنة 2021م }
$$

\section{القسم الثالث: الدراسة الميدانية}

إجراءات الجانب الميداني:

هـدفت الدراســة الميدانيـة إلى الكسشف عـن الـصعوبـات الـتي تواجسه دور جامعــة أم

القـرى يْ تفعيـل العمـل التطـوعي، وكذا سُبـل التغلـب على هـذه الصعوبـات مـن وجهـة

$$
\text { نظر طالباتها، وفيما يلي توضيح لإجـراءات هذا الجـانب الميداني: }
$$

1- مجتمعـوعينـة الدراسية:

بلغ حجم المجتمع الأصلي (10280) طالبة، وبالرجوع إلى جداول حسابات العينة

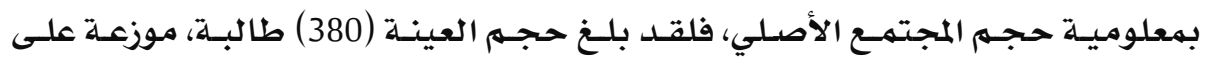

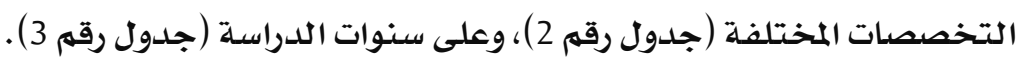

\begin{tabular}{|c|c|c|c|}
\hline حجم العينة & ما تم توزيعه & حجم المجتمع & التخصص \\
\hline 48 & 55 & 1295 & العلوم الشرعية \\
\hline 221 & 235 & 5978 & العلوم الاجتمعاعيـة \\
\hline 111 & 120 & 3007 & اللغـة العربيـة \\
\hline 380 & 410 & 10280 & مجموع الطالبـات \\
\hline
\end{tabular}

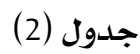

يوضتح حجم مجتمهـ الدراسـة وما تم توزيعها وعينـة الدراسـة

\begin{tabular}{|c|c|c|}
\hline النسبة & 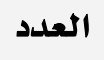 & التخصص \\
\hline$\% 12.63$ & 48 & العلوم الشرعية \\
\hline$\% 58.16$ & 221 & العلوم الاجتماعية والتربوية \\
\hline$\% 29.21$ & 111 & اللغة العربية \\
\hline$\% 100$ & 380 & المجموع \\
\hline
\end{tabular}

جدول (3) 


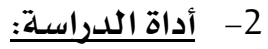

وكمها أوضـحنا اختـارت الدراسـة "الاستبانة" كـأداة لمناسبتها موضـوع، وإضـافة

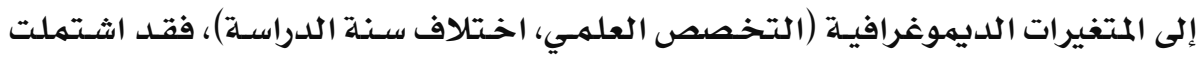
على محورين:

أ- صعوبات دور جامعة أم القرى يِّ تنمية قيم العمل التطوعي لدي الطالبات.

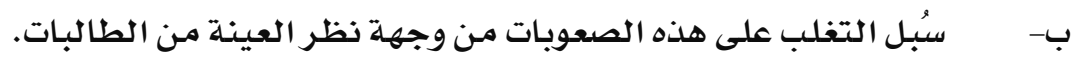
3- الصدق الداخلي (الاتساق الداخلي) Internal consistently Validity وقد تم التأكد من تماسك عبارات الاستبانة، حيث قامت الباحثة بحساب صدق الاتساق الداخلي للاستبانة على عينة استطلاعية مكونة من (30)

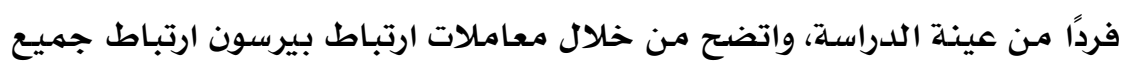

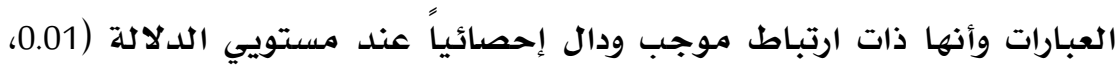
0.05)، مما يدل على صدق الاتساق الداخلي على مستوى جميع العبارات. 4- ثبـات الأداة:

وقد قامـت الباحثة بحسـاب ثبـات الاستبانة وذلك باستخدام معامل ثبـات

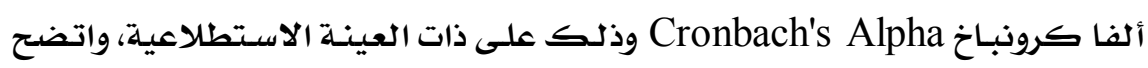

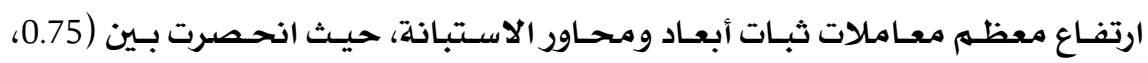
0.94)، كما بلغ معامل ثبات ألفا كرونبـاخ لإجمالي الاستبانة (0.95) وهو معامـل

$$
\text { ثبات مرتفع. }
$$

5- الأساليب الإحصائيـة المستخدمـة:

$$
\text { - التكرارات والنسب المئوية لوصف خصائص أفراد العينة. }
$$

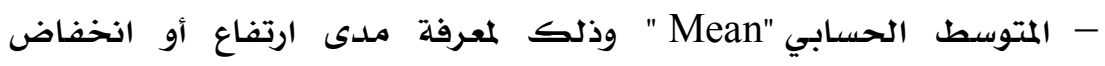

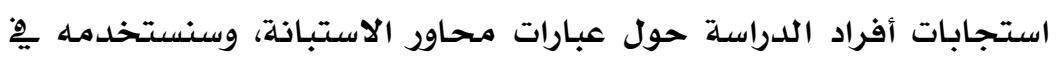
ترتيب العبارات، وعند تساوي المتوسط الحسابي سيكون الترتيب حسب أقل قيمة للانحراف المعياري. - تم استخدام الانحراف المعياري "Standard Deviation" للتعرف على إنى مدى انحراف استجابات أفراد الدراسة لكل عبارة من عبارات محاور

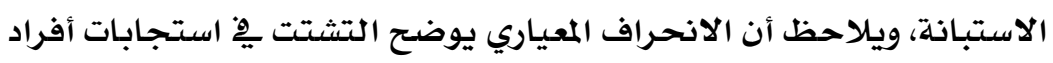




$$
\begin{aligned}
& \text { كلية التربية بالاقهاهرة العدد: ( 189)، الجزء (الثاني)، يناير لسنة 2021م } \\
& \text { مجلة التربية }
\end{aligned}
$$

عينة الدراسة حول كل عبارة، فكلما اقتربت قيمته من الصفر تركزت الاستجابات وانخفض تشتتها بين المقياس.

$$
\begin{aligned}
& \text { - معامل ارتباط "بيرسون" لقياس صدق الاستبانة. } \\
& \text { - معامل ثبات "ألفا كرونباخ" لقياس ثبات الاستبانة. } \\
& \text { وفيما يلي عرض ومناقشة نتائج التطبيق الميداني: }
\end{aligned}
$$$$
\text { القسم الرابع: عرض ومناقشة النتائج }
$$

السؤال الأول: ما الصعويات التي تواجه دور جامعة أم القرى فِّ تنمية قيم العمل

$$
\text { التطوعي لدى الطالبيات؟ }
$$

وقد أوضحت النتائج وجود صعوبات تتوزع هِّ ثلاثة مجموعات:

أ- صعوبات تعود إلى شخصية الطالبة (جدول رقم 4):

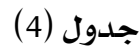

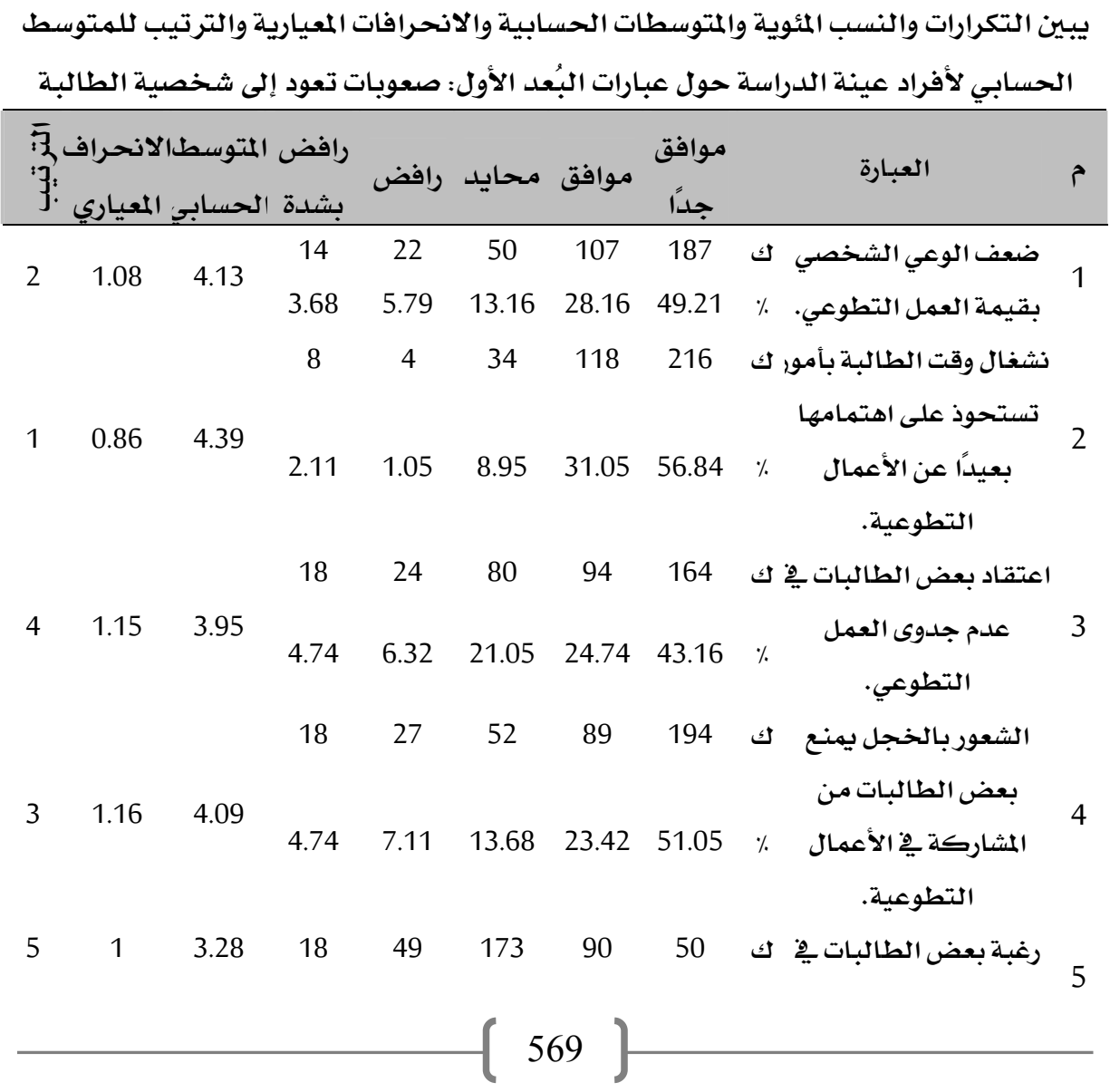




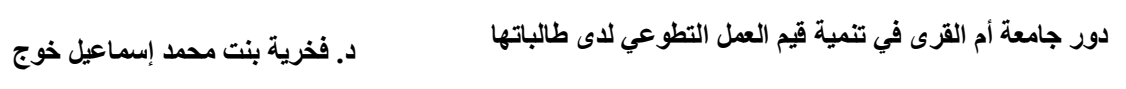

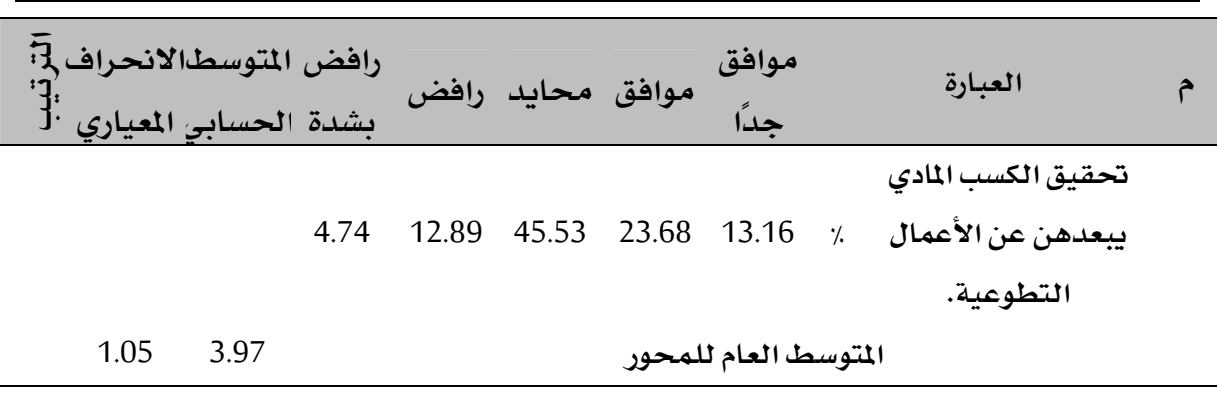

يتضح من الجدول أعلاه وجهات نظر أفراد عينة الدراسـة من طالبـات جامعة أم

القـرى حـول درجـة مـوافقتهن على عبـارات بُعـد صسعوبات تعـود إلى شخـصيـة الطالبـة،

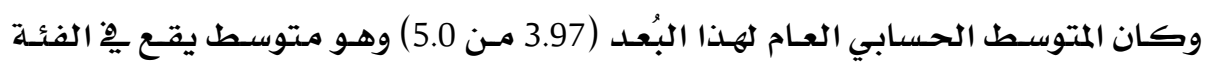
الرابعـة من فئكات المقياس الخماسي مها يعني أن أفراد عينــة الدراســة مـن طالبـات جامعـة

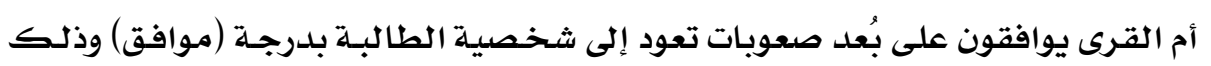
بشكل عام.

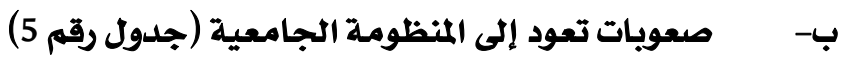

جدول (5)

يبين التكرارات والنسب المئوية والمتوسطات الحسابية والانحرافات المعيارية والترتيب

للمتوسط الحسابي لأفراد عينة الدراسة حول عبارات البُعد الثاني: صعوبات تعود إلى

المنظوممة الجامعية

\begin{tabular}{|c|c|c|c|c|c|c|c|c|c|c|}
\hline 氛羿: & الانحراف & المتوسط الحسابي & رافض بشدة & رافض & محايل & موافق & موافق جلًا & & العبارة & r \\
\hline \multirow{5}{*}{1} & \multirow{5}{*}{0.64} & \multirow{5}{*}{4.68} & 4 & $\mathbf{0}$ & 12 & 82 & 282 & ك & انشغال الطالبة & \\
\hline & & & & & & & & & الجامعي & 1 \\
\hline & & & 1.05 & 0 & 3.16 & 21.58 & 74.21 & $\%$ & بالدراسة & \\
\hline & & & & & & & & & والامتحانات. & \\
\hline & & & 4 & 4 & 36 & 120 & 216 & ك & صعوية تحقيق & \\
\hline \multirow[t]{3}{*}{2} & \multirow[t]{3}{*}{0.79} & \multirow[t]{3}{*}{4.42} & & & & & & & التوازن بين & 2 \\
\hline & & & 1.05 & 1.05 & 9.47 & 31.58 & 56.84 & $\%$ & لعمل التطوعي: & \\
\hline & & & & & & & & & والدراسة. & \\
\hline \multirow{5}{*}{6} & \multirow{5}{*}{0.87} & \multirow{5}{*}{3.94} & 8 & 18 & 52 & 211 & 91 & ك & ضعف وجود & \\
\hline & & & & & & & & & تعزيز كاف & \\
\hline & & & 211 & 17 & 1250 & $55=2$ & ז0 בר & & لعمل التطوعي & 3 \\
\hline & & & & & & & & & من قبل & \\
\hline & & & & & & & & & الزميلات. & \\
\hline
\end{tabular}




$$
\text { كلية التربية بالقاهرة العدد: ( 189)، الجزء (الثاني)، يناير لسنة 2021م }
$$

\begin{tabular}{|c|c|c|c|c|c|c|c|c|c|c|}
\hline 氛 & الانحراف & المتوسط الحسابي & رافض & رافض & مححايد & موافق & موافق جدًا & & العبارة & 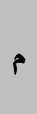 \\
\hline \multirow{4}{*}{5} & \multirow{4}{*}{0.9} & \multirow{4}{*}{4.04} & 12 & 12 & 36 & 208 & 112 & ك5 & ضعف وضوح & \multirow{4}{*}{4} \\
\hline & & & & & & & & & & \\
\hline & & & 3.16 & 3.16 & 9.47 & 54.74 & 29.47 & $\%$ & كاف للأعمال & \\
\hline & & & & & & & & & التطوعية. & \\
\hline \multirow{3}{*}{8} & \multirow{3}{*}{1.57} & \multirow{3}{*}{3.19} & 102 & 26 & 53 & 96 & 103 & ك & ضعف وضوح & \multirow{3}{*}{5} \\
\hline & & & 2694 & 684 & 1305 & $25 ? 6$ & 2711 & 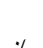 & برامج تطوعية & \\
\hline & & & 20.07 & 0.07 & נד.ניו & 20.20 & 28.11 & 1. & تبناها الجامعة & \\
\hline \multirow{4}{*}{4} & \multirow{3}{*}{0.95} & \multirow{3}{*}{4.08} & 16 & 10 & 30 & 196 & 128 & ك & خلو المقررات مز & \multirow{3}{*}{6} \\
\hline & & & & & & & & & الاثمارة إلى & \\
\hline & & & 4.21 & 2.63 & 7.89 & 51.58 & 33.68 & $\%$ & أهمية العمل & \\
\hline & \multirow{4}{*}{1.16} & \multirow{4}{*}{3.2} & 26 & 96 & 86 & 121 & 51 & ك ك & نقص القدوات & \multirow{4}{*}{7} \\
\hline \multirow{3}{*}{7} & & & & & & & & & الجامعية 2ِ & \\
\hline & & & 6.84 & 25.26 & 22.63 & 31.84 & 13.42 & $\%$ & مجال العمل & \\
\hline & & & & & & & & & & \\
\hline \multirow{6}{*}{3} & \multirow{5}{*}{0.93} & \multirow{5}{*}{4.23} & 4 & 20 & 46 & 124 & 186 & ك & نقص برامج & \\
\hline & & & & & & & & & الارثشاد & \\
\hline & & & & & & & & & والتوجيه التي & 8 \\
\hline & & & 1.05 & 5.26 & 12.11 & 32.63 & 48.95 & $\%$ & تشرح العمل & \\
\hline & & & & & & & & & التطوعي. & \\
\hline & 0.98 & 3.97 & \multicolumn{8}{|c|}{ المتوسط العام للمحود } \\
\hline
\end{tabular}

يتضـح مـن الجدول أعلاه وجهات نظر أفراد عينـة الدراسـة من طالبـات جامعـة أم

القـرى حـول درجـة مـوافقتهن على عبـارات بُعـــ صـعوبـات تعـود إلى المنظومـة الجامعيـة، وكـان المتوسـط الحسـابي العـام لهـذا البُعـد (3.97 مـن 5.0) وهـو متتوسـط يقـع مِِ الفئسة الرابعـة من فئات المقياس الخماسي مها يعني أن أفراد عينـة الدراسـة مـن طالبـات جامعـة أم القرى يوافقون على بُعد صعوبـات تعود إلى المنظومـة الجـامعية بـدرجة (موافق) وذلك 


\section{ج- صعوبات تعود المنظومة المجتمعية (جدول رقم6)}

جدول (6)

يبين التكرارات والنسب المئوية والمتوسطات الحسـابية والانحرافات المعيارية والترتيب للمتوسط الحسابي لأفراد عينـة الدراسـة حول عبارات البُعد الثالث: صعوبات تعود إلى المنظومـة المجتمعية

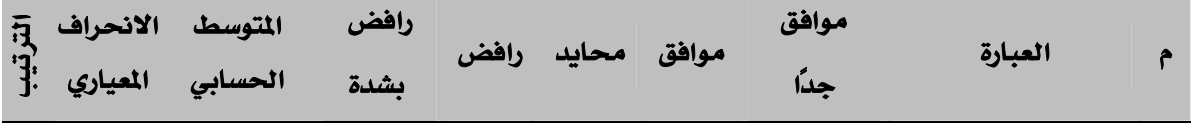

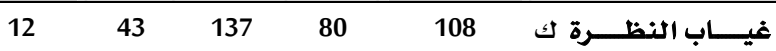

$\begin{array}{lll}11 & 1.11 \quad 3.6\end{array}$

$\begin{array}{llll}3.16 & 11.32 & 36.05 & 21.05\end{array}$

الاجتماعيـة الـتي

3.

18

$\begin{array}{lll}4 & 51 \quad 233\end{array}$

تقــــدر الأعمــال \% \%

التطوعية.

$\begin{array}{lll}6 & 0.89 & 3.9\end{array}$

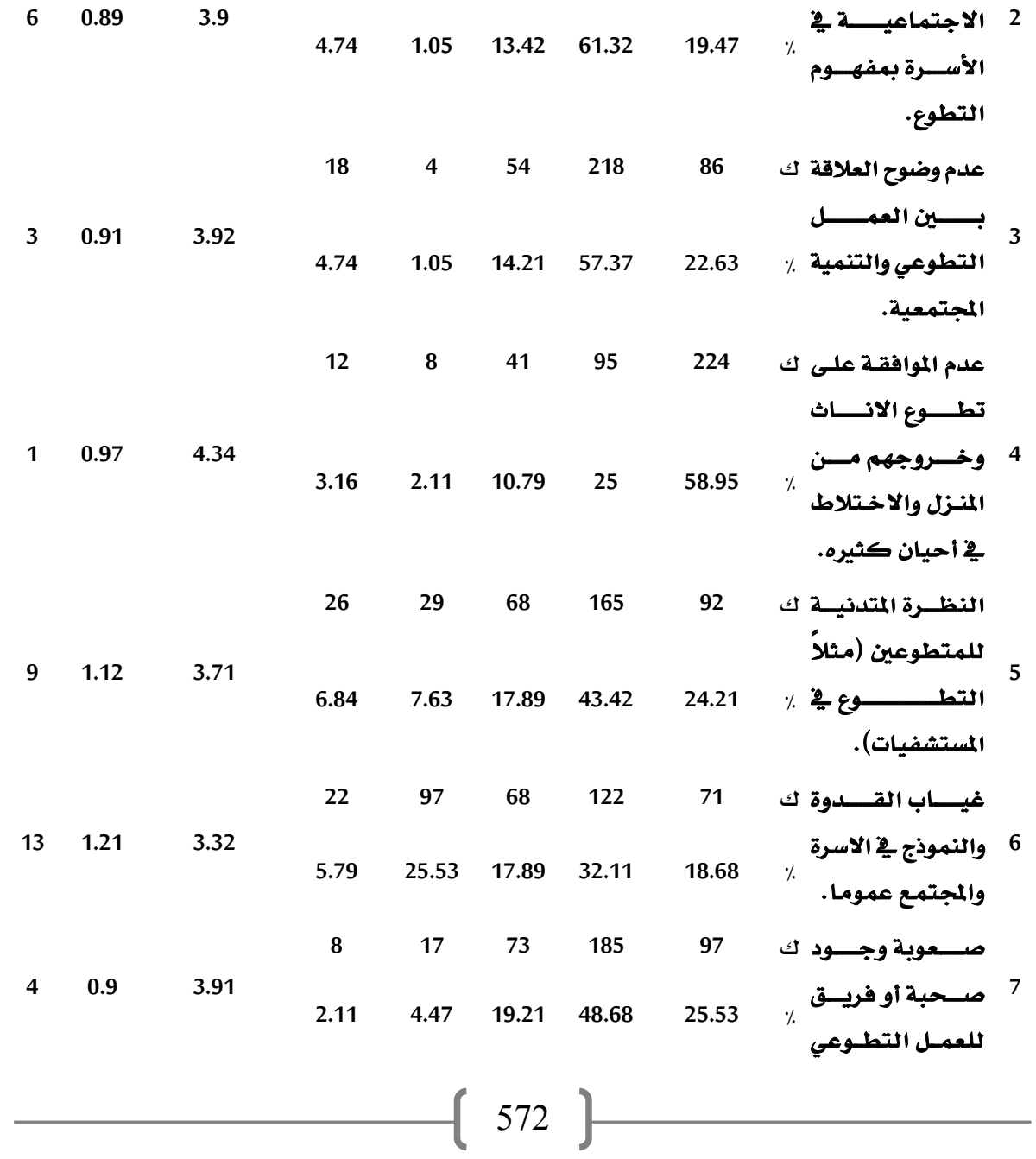

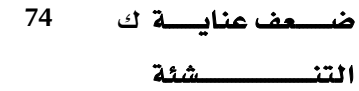




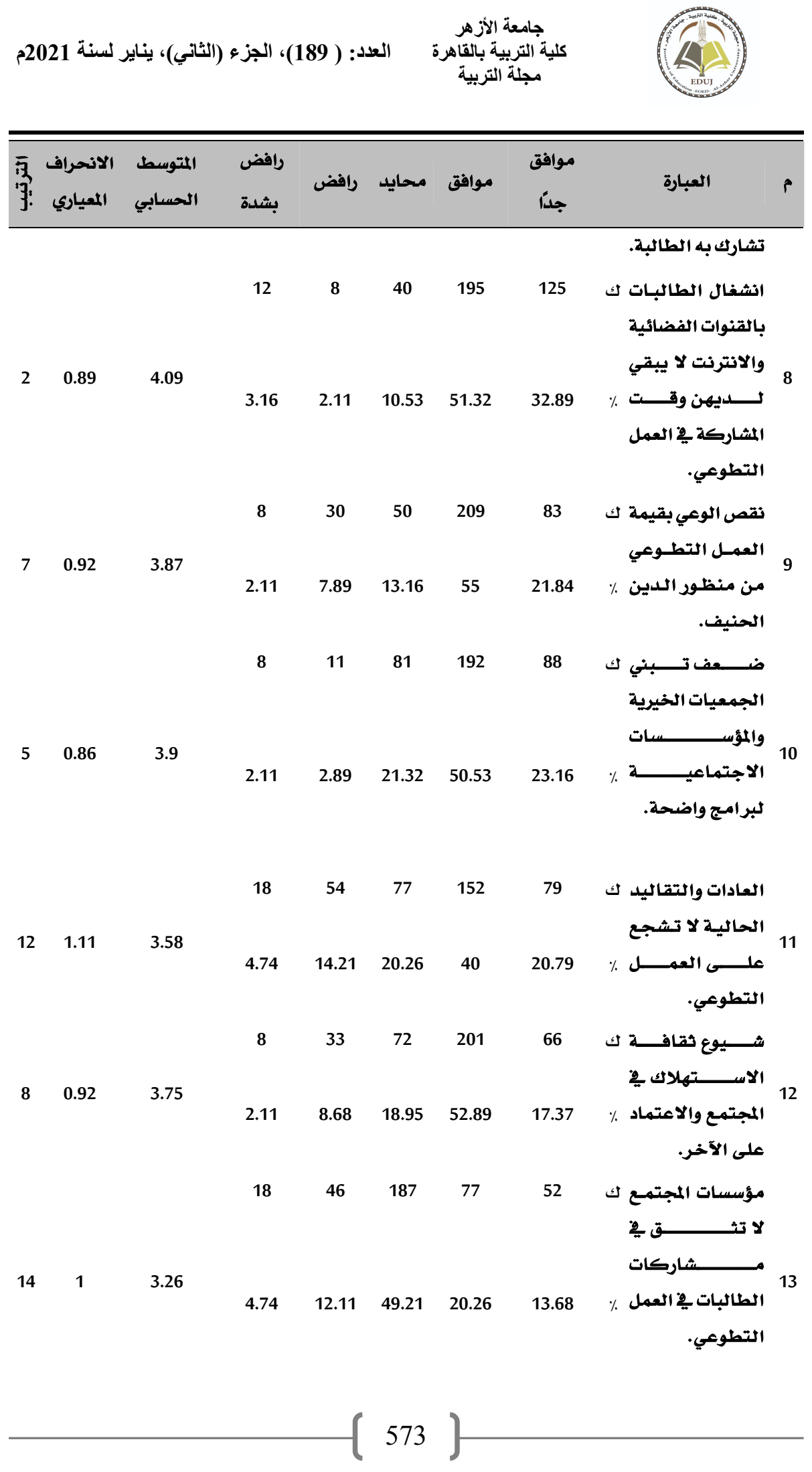




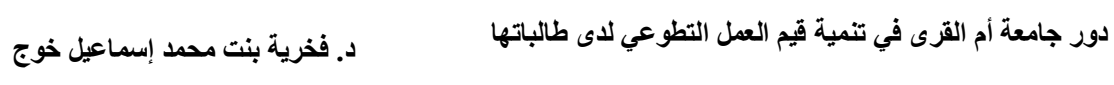

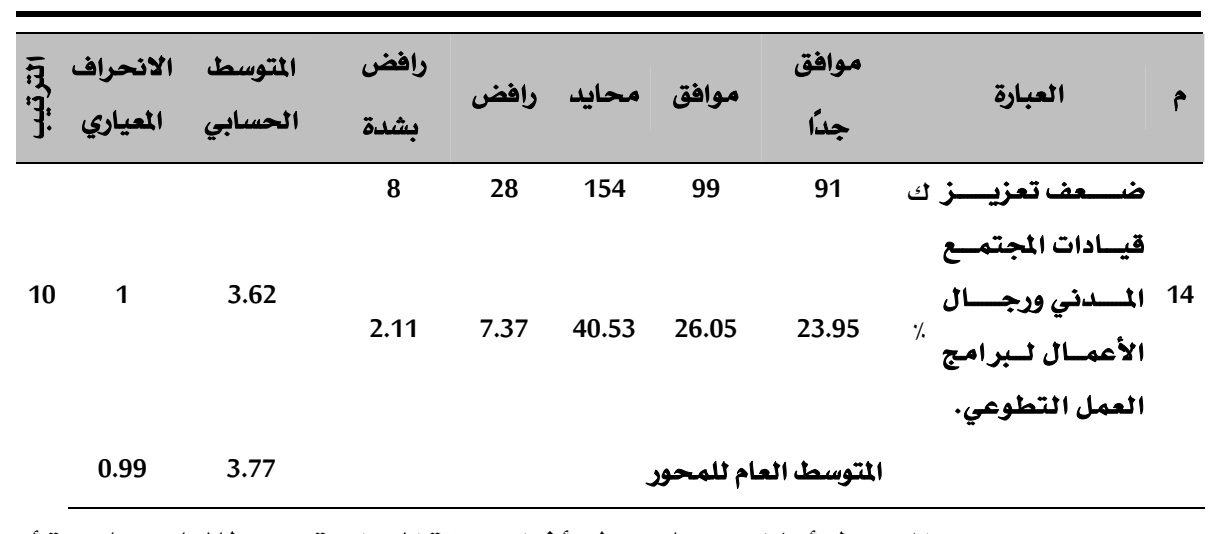

يتضسح من الجدول أعلاه وجهات نظر أفراد عينـة الدراسـة من طالبـات جامعـة أم

القـرى حـول درجـة مـوافقتهن على عبـارات بُعـد صسعوبات تعـود إلى المنظومـة المجتمعيـة،

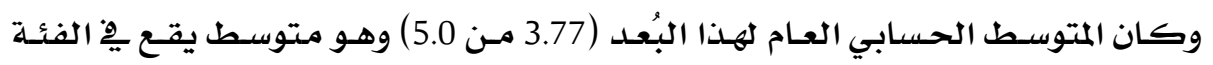
الرابعـة من فئـات المقياس الخماسي مها يعني أن أفراد عينـة الدراسـة مـن طالبـات جامعسة

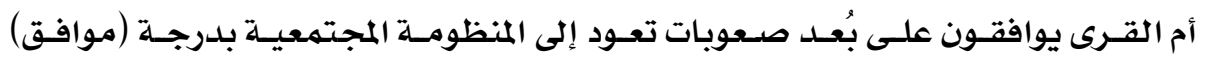
وذلك بشكل عام.

وفيما يلي نتنـاول المقارنـة بـين المتوسطات الحسبابية لأبعـاد محسور صعوبـات دور

الجامعة ِِّْ تنميلة قيم العمل التطوعي لدى طالباتها:

جدول (7) (7)

يوضـح المتوسطات الحسابية لأبعاد صعوبات دور الجامعـة يِ تنمية قيم العمل التطوعي

\begin{tabular}{|c|c|c|c|}
\hline الترتيب & درجـة & المتوسط الحسابي & البُعد \\
\hline 1 & موافق & 3.97 & البُعد الأول: صعوبـات تعود إلى شخصيـة \\
\hline 1 & موافق & 3.97 & البُعد الثاني: صعوبـات تعود إلى المنظومـة \\
\hline 3 & موافق & 3.77 & البُعدد الثالث: صعوبـات تعود إلى المنظومـة \\
\hline \multicolumn{2}{|c|}{ متوسطة } & 3.90 & المتوسط العام لمحور معوقات دور الجامعة يِّ \\
\hline
\end{tabular}


يتضح من الجدول السابق أنه المتوسط الحسابي العام لمحور صعوبات دور الجامعة

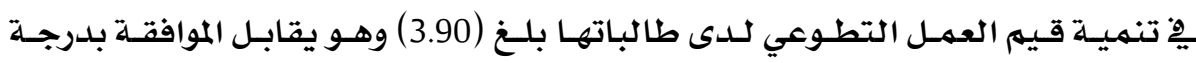

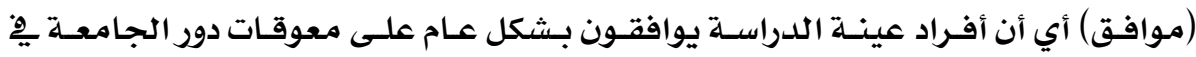

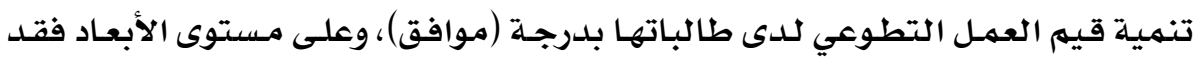

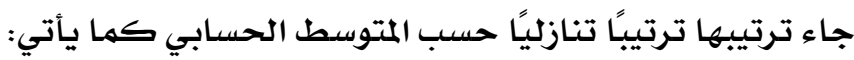
- جاءا بُعدي (صعوبات تعود إلى شخصية الطالبة، صعوبات تعود إلى المنظومـة

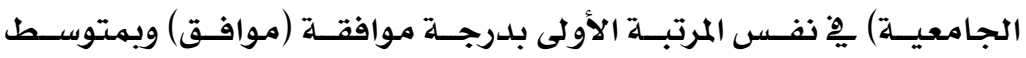

$$
\text { حسابي (3.97) لكل منهما. }
$$

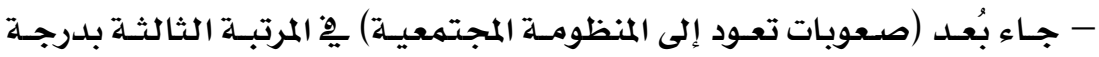

$$
\text { موافقة (موافق) وبهتوسط حسابي (3.77). }
$$

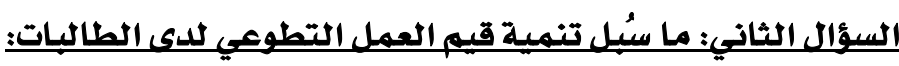

وللإجابـة علسى السؤال السـابق وللتعـرف على تعزيـز دور الجامعـة يِّ تنميـة قيهم

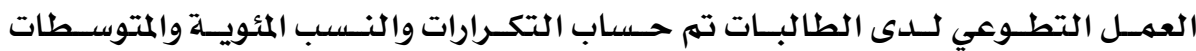
الحسـابية والانحرافـات المعياريـة والترتيـب للمتوسط الحسـابي لعبـارات المحسور الثـاني:

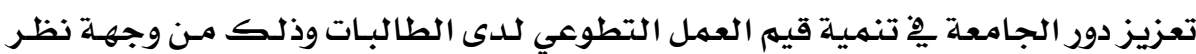
أفراد عينة الدراسة من الطالبات كما هو موضح فيما يأتي: جدول (8) (8)

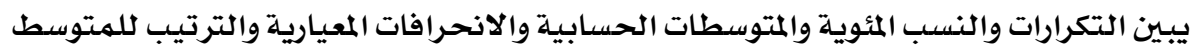
الحسابي لأفراد عينة الدراسة حول عبارات المحور الثاني: تعزيز دور الجامعة ِِّ تنمية قيم

العمل التطوعي لدى الطالبات

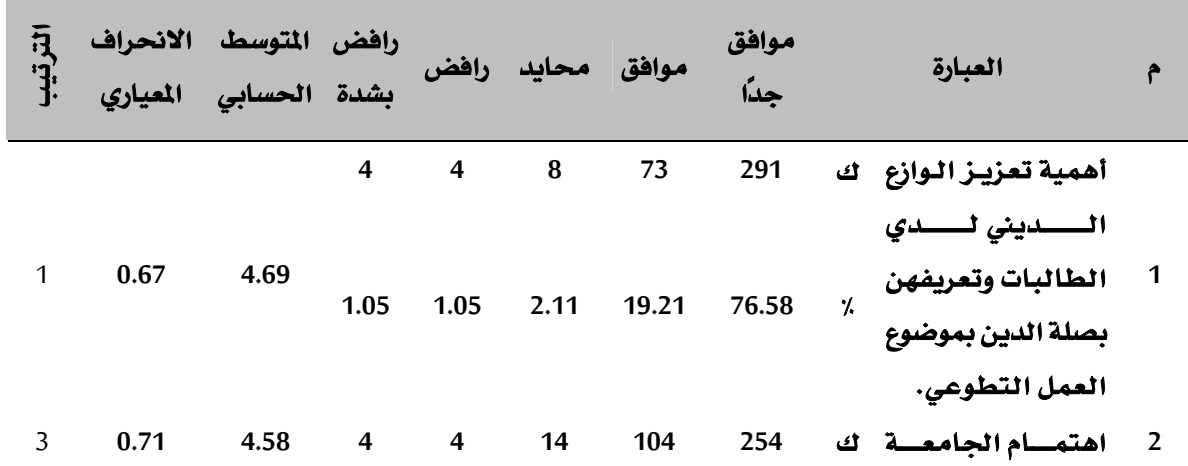




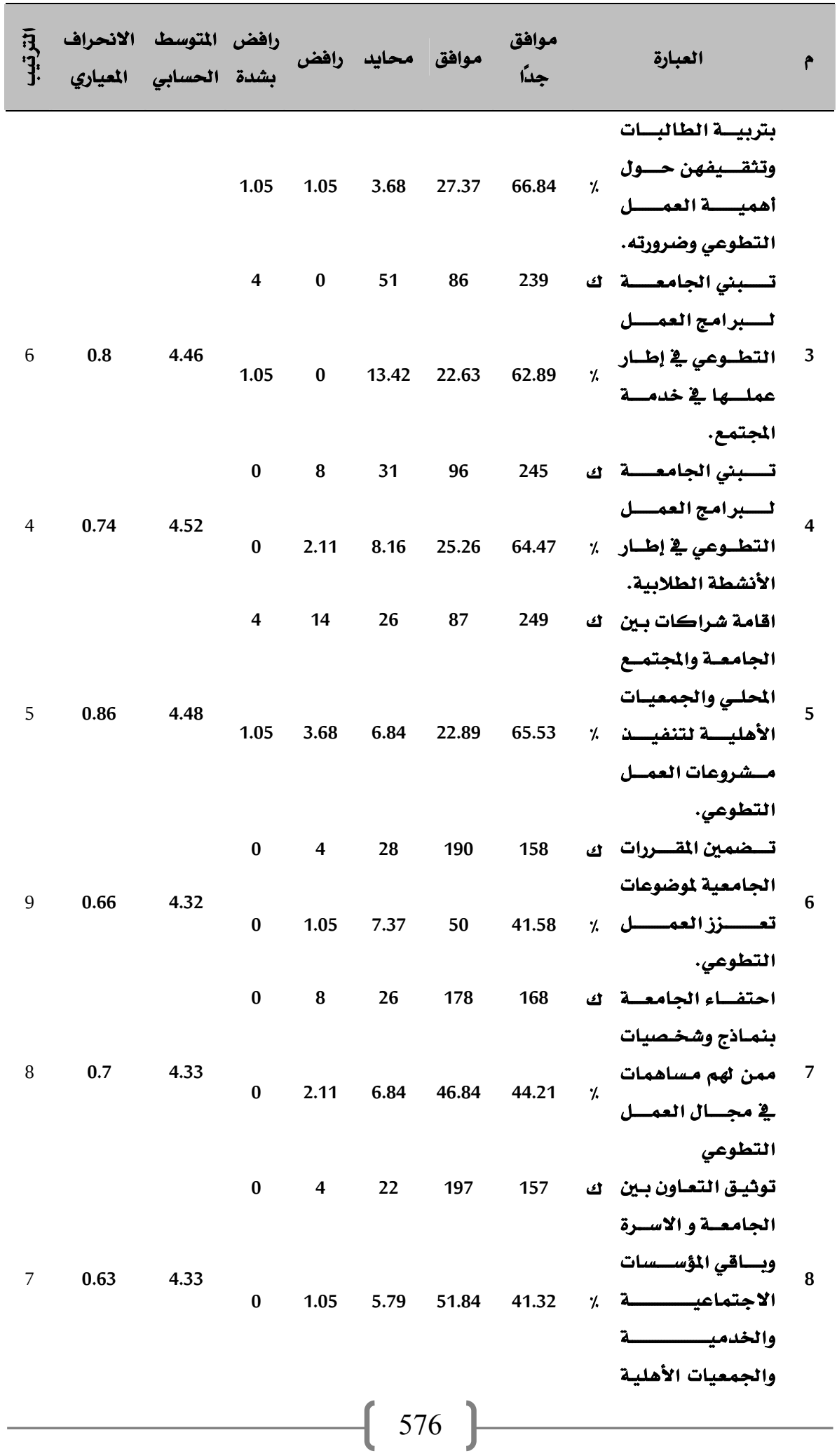




$$
\begin{aligned}
& \text { كلبة التربية بالقاهرة العدد: ( 189)، الجزء (الثاني)، يناير لسنة 2021م } \\
& \text { مجلة التربية }
\end{aligned}
$$

رافض المتوسط الانحراف

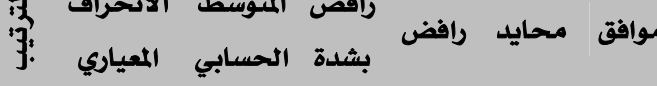

$$
\text { موافقا }
$$

العبارة التطوعي

$\begin{array}{llllll}0 & 4 & 18 & 97 & 261 & 5\end{array}$

ومهـارات الطالبـات

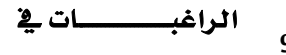

الانسمام للأعمـال

التطوعيـة مـن قبـل

الكلية والجامعة.

يتـــح مـن الجــول أعـلاه وجهـات نظـر أفـراد عينــة الدراســة مـن طالبـات جامعـة أم القرى حول درجـة موافقتهن على عبارات محور تعزيز دور الجامعـة ِِّْ تنميـة قيهم العهـل التطوعي، وكان المتوسط الحسـابي العـام لهذا المحسور (4.48 مـن 5.0) وهـو متتوسط يقـع

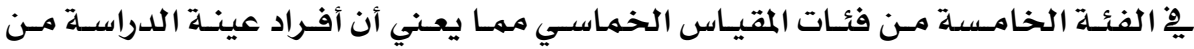
طالبـات جامعـة أم القـرى يوافقـون على عبـارات هـذا المحسور بـدرجـة (موافق جـدًا )وذلكـ بشكل عام.

هذا وقد رأى أفراد عينة الدراسة من طالبيات جامعة أم القرى أن على الجامعة أدوار أخرى لتعزيز دور الجامعة 2خ تنمية قيم العمل التطوعي للى الطالبيات منها: - وضع نقاط وميزات وتسهيلات للعمل التطوعي مـثلا زيـادة عدد اسـعارة الكتب من المكتبـة

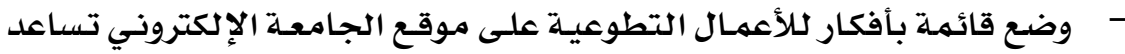
الراغبين بالتعرف عليها والتواصل مـع جهات الاختصاص. 


\section{القسم الخخامس: خلاصة النتائج والتوصيات:}

تِعهيد:

مـن العـرض السـابق لنتــائج الدراسـة الميدانيـة، نعـرض فيهـا يلـي خلاصسة تلـك

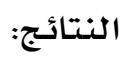

المحور الأول: صعوبات دور الجامعة يِ تنمية قيم العمل التطوعي لدى طالباتها: • بلغ المتوسط الحسابي العام لمحور صعوبات دور الجامعة يْ تنمية قيم العمل التطوعي لدى طالباتها (3.90) وهو يقابل الموافقة بـدرجة (موافق).

• جاءت موافقة أفراد عينة الدراسـة بلدرجـة (موافق) على جميع أبعاد محور صعوبات دور الجامعة يِّ تنميلة قيهم العمل التطوعي لدى طالباتها . البُعد الأول: صعوبات تعود إلى شخصية الطالبة: • أبدى أفراد عينـة الدراسة من طالبـات جامعة أم القرى استجابة على بُعد (صعوبات تعود إلى شخصيـة الطالبة) بـرجـة (موافق) وذلك بوجه عام. • وقد رأى أفراد عينـة الدراسة من طالبات جامعة أم القرى بعض الصعوبات الشخصيـة الأخرى وهي: - أسباب متعلقة بعدم توفر وسيلة نقل. - التربيـة الأسـريـة (المنزل والأسـرية) حيث أنها تربط بين مفهوم التطوع بلا استغلال وعدم المطالبـة بالحقوق. - مغف الإعلانات عن أنواع الأعمال التطوعية المناسبـة للطالب داخل الجامعة. - - ضعف الوعي عن أهمية التطوع يٍِ الدين والحياة. البُعد الثاني: صعوبات تعود إلى المنظومة الجامعية: • أبدى أفراد عينـة الدراسة استجابة على بُعد صعوبات تعود إلى المنظومة الجامعيـة بـرجـة (موافق) وذلك بوجـه عام. البُعد الثالث: صعوبات تعود إلى المنظومة المجتمعية: • أبدى أفراد عينة الدراسـة استجابـة على بُعد صعوبات تعود إلى المنظومـة المجتمعية بـدرجة (موافق) وذلك بوجـه عام.

المحور الثاني: تعزيز دور الجامعة يِ تنمية قيم العمل التطوعي لدى الطالبات: • أبدى أفراد عينـة الدراسـة استجابة على محور تعزيز دور الجامعة يِّ تنميلة قيم 
العهل التطوعي لدى الطالبات بدرجة (موافق جدًا) وذلك بوجه عام.

رأى أفراد عينة الدراسة من طالبات جامعة أم القرى أن على الجامعة أدوار

أخرى لتعزيز دور الجامعة يِّ تنمية قيم العمل التطوعي لدى الطالبـات منها :

وضع نقاط وميزات وتسهيلات للعمل التطوعي مثلا زيادة عدد استعارة الكتب

$$
\text { من المكتبة }
$$

وضع قائمة بأفكار للأعمال التطوعية على موقع الجامعة الإلكتروني تساعد

الراغبين بالتعرف عليها والتواصل مع جهات الاختصاص.

التوصيات:

من قراءة النتائج الميدانية وواقع البرامج المقدمة لطالبات جامعة أم القرى، ودور

الجامعة ِِّ تعزيز قيم العمل التطوعي، خُلصت الدراسة إلى التوصيات الآتية:

1. أن تعمل الكلية على إكساب الطالبات قيهم العمل التطوعي على المستوى النظري

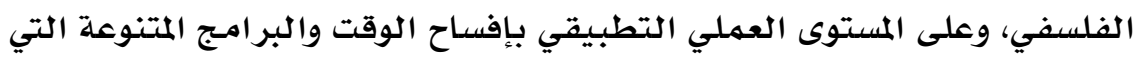

تلائم ميول وقدرات الطالبات وتخصصاتهن.

2. مشاركة الطالبات يِّوضع الخطط والبرامـج التي تعدها الكلية ِِِ مجال العمل

التطوعي، وذلك من خلال المسوح واستطلاعات الرأي التي تقدم لهن.

3. تقويم الأعمال التطوعية التي تقدمها الكلية للمجتمع من خلال دراسات وقياسات علمية تطبق على الطالبات وعلى المستفيدين من إنجازات الأعمال التطوعية، وعلى أن يتم ذلك من خلال وحدة متخصصة بالجامعة.

4. تنمية الوازع الديني لدى الطالبات بجدوى العهل التطوعي من الوجهة الشرعية بتجلية الأسس الشرعية من واقع الكتاب والسنة وأعمال الفقهاء وكتابات المفكرين المسلمين، وعلى أن يتم ذلك من خلال ندوات متخصصة يدعى إليها الدعاة والمتخصصون يِّ العلوم الشرعية. 
5. إثابة الطالبات من أصحاب التميز ِِّ العمل التطوعي بشتى مظاهر التكريه، وتحديد يوم ِِّ العام (يوم العمل التطوعي)، يتم فيه تكريم هؤلاء الطالبات بالشهادات والأوسمة.

6. إنشاء قاعدة بيانات العمل التطوعي بالجامعة تشارك فيها كافة الجهات

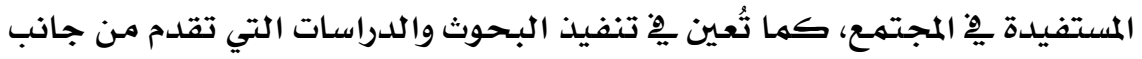
أعضاء هيئات التدريس والطالبات.

7. وضع خطط استراتيجية جامعية للعمل التطوعي والاستعانة ِِّ ذلك بالخبراء

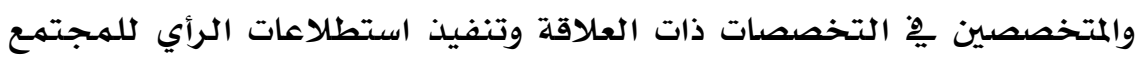
الخارجي لتقصي المبادرات والمثروعات التي تتبناها الجامعة والتي تمثل أولوية

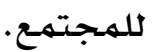

8. تخصيص موقع إلكتروني تفاعلي للجامعة يعرض مبادراتها وبرامجها يِّ مجال العمل التطوعي وتلقي رؤى ومقترحات المستفيدين من الجمعيات والمؤسسات الاجتماعية حول سُبل تعزيزوتطوير دور الجامعة.

9. أهمية أن تطلع الجامعة بدور تثقيفي للمحيط الاجتماعي لتعزيز نظرة المجتمع حيال العمل التطوعي، ويمكن لأجهزة وأدوات التواصل الاجتماعي أن تؤدي دورًا مهمًا ِيْ هذا الاتجاه. 10.تضمين برامج التنمية المهنية لأعضاء هيئة التدريس موضوعات تتعلق بثقافة العمل التطوعي ومنهجية تعزيز قيم العمل التطوعي لدى الثباب الجامعي. 


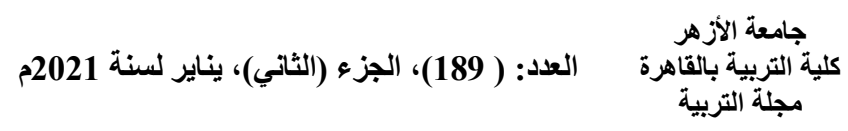

ضيف الله بن سليم البلوى: واقع العمل التطوعي بالمملكة العربية السعودية يِّ [ العمل التطوعي،

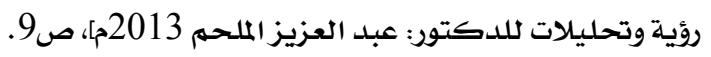

2- المملكة العربيـة السعودية، قـرار مجلس الشورى رقم (65/123) بتـاريخ 1432/01/13هـ

المتضمن مشروع (نظام العمل التطوعي).

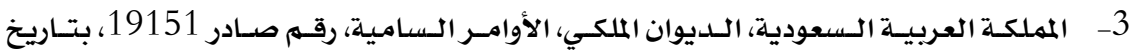

$$
\text { 1434/05/21 }
$$

4- عبد الله الخطيب، دور العمل التطوعي يّْ تحقيق الأمن والسلام الاجتماعيين، مـؤتمر العمل

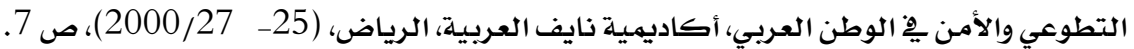

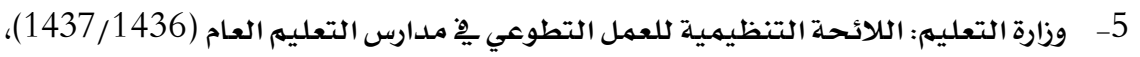

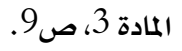

6

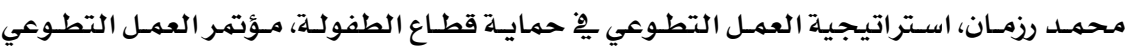

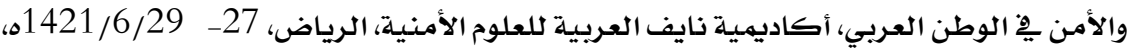

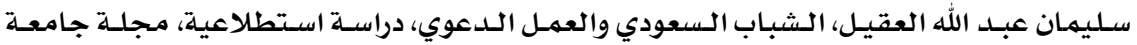

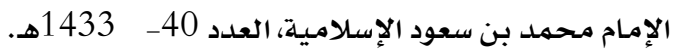
عثمـان بـن صـالح العـامر، ثقافة التطوع لـدى الشبـاب السعودي، دراسـة ميدانية، مديريـة التربيـة

$$
\text { والتعليهم بحائل، 1425هـ، صنان بن } 26 .
$$

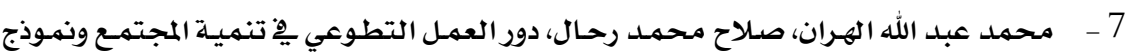

$$
\text { كتفعيلة، 2011، ص18. }
$$

1 - محمد عاطف غيث، قاموس علم الاجتماع، دار المعرفة الجامعية، 2009، صو89.89.

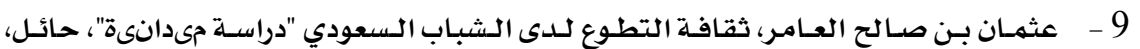

$$
\text { 1425، صـ } 13
$$

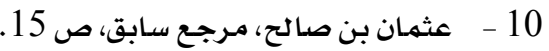

11 - الشبكة العربية للمنظمات الأهلية، الموسوعة العربية للمجتمع المدني، محرر (أماني قنديل)، القاهرة، 2008، ص ص 87-

12 - الـبكة العربيـة للمنظمـات الأهليـة، الموسـوعة العربيـة للمجتهـع المـدني، محسرر (أمـاني

قنديل)، القاهرة، 2008، ص ص 87- 89. 
13 - عبـد الناصـر فخـرو، تعزيـز ثقافـة العهـل التطـوعي لـــى طـلاب الجـامعـة بـالكويـ، إطـار تصوري مقترح، جامعة الكويت، 2010م، ص

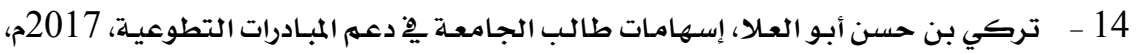

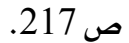
15- القرطبي، أبو عبد الله محمد بن أحمد، الجامـع لأحكام القرآن والمبين لما تضمنه مـن السنـة وأي الفرقان، تحقيق عبد الله التركي، ط1 (بيروت، مؤسسة الرسالة، 1427هـ) 16- الطبري، أبو جعفـر محمــ بـن جريـر، تفسير الطبري جـامع البيـان عن تأويـل أي القـرآن،

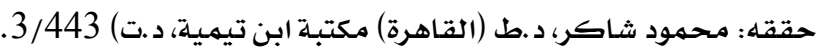

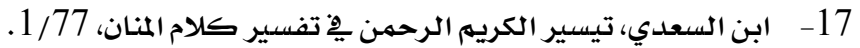
18- أخرجه البخاري يِ صحيحـه من طريق عبد الله بن عمر رضي الله عنه، كتاب المظالم، باب

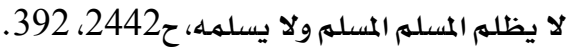

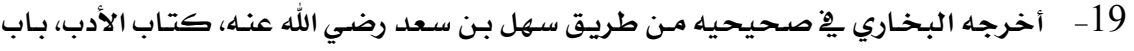

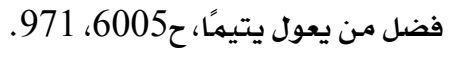
20- أخرجه مسلهم ِِّ صحيحيه من طريق عثمان بن عفان رضي الله عنه، كتاب المساجد، بـاب

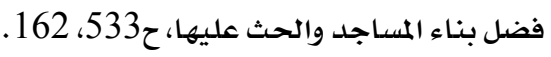
21- الدبل، صالح عبد الله، الخثلان، إبراهيم زيلد، المؤسسات الإسلامية ورعاية الأعمـال الخيريـة والتطوعيـة، بحـث مقـدم إلى المؤتمـر العلمـي الأول للخدمـة التطوعيـة بالمملكسة، جامعـة أم القـرى،

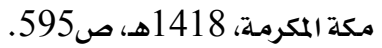

22- فهد بن سلطان السلطان، اتجاهات الشباب الجامعي الذكور نحو العمل التطوعي، دراسـة

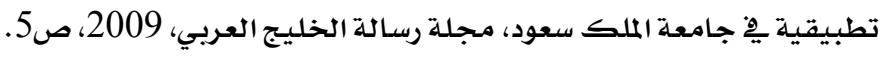
23- مصطفى عبد القادر زيادة، الأصول الفلسفية للتربية، مبحث القيه، منشورات جامعة عين

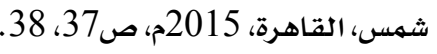
24- من أهم الدراسات التي تناولت أسـاليب تعزيز قيهم التطوع لدى طلاب الجامعات السعودية:

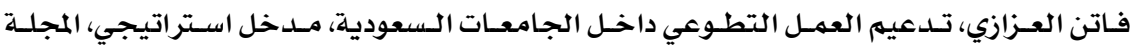
الدولية التربوية المتخصص، 2014م، ص 166 - 182.

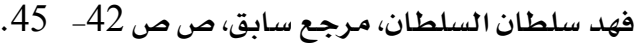

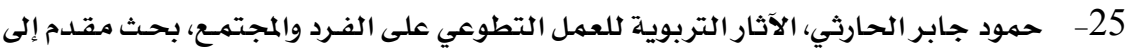
مؤتمر العمل التطوعي وآفاق المستقبل، جامعة أم القرى، مكة المكرمة،

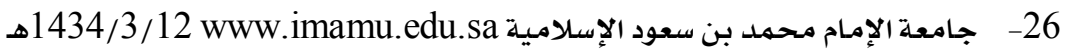

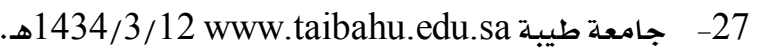
28 - جامعة الملك فهد للبترول والمعادن 1434/3/12 Www.medadcenter.comهـ.

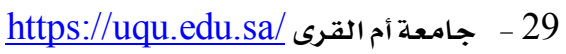




$$
\begin{aligned}
& \text { كلية التربية بالقاهرة العدد: ( 189)، الجزء (الثاني)، يناير لسنة 2021م } \\
& \text { مجلة التربية }
\end{aligned}
$$

من تصميم الباحثة، نتائج الدراسة الميدانية للبحث الحالي.

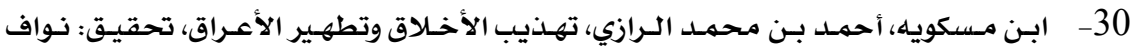

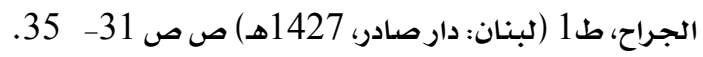

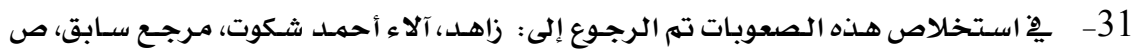

ص 115- (123. n 120

ثانيا : المراجـع العربيـة: مل

ضـيف الله، بـن سـليهم البلـوى (2013). واقـع العهـل التطـوعي بالمملكـة العربيـة السعودية فِ [ العمهل التطوعي، رؤية وتحليلات لللاكتور: عبد العزيز الملحهم.

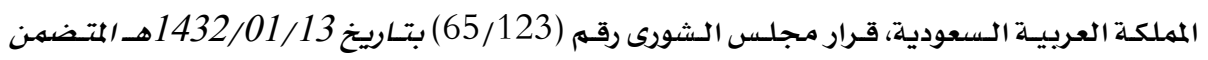
مشروع (نظام العمل التطوعي).

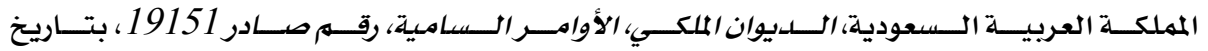
1434/05/21

عبد الله، الخطيب (2000) ـ دور العمل التطوعي فِ تحقيق الأمسن والسلام الاجتهماعيين. مـؤتمر العمل التطوعي والأمن فِ الوطن العربي. أكاديمية نايف العربية، الرياض.

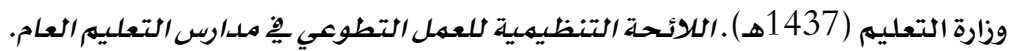

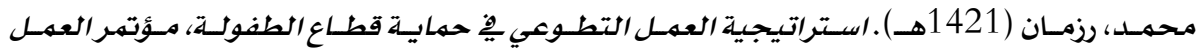
التطوعي والأمن فِ الوطن العربي. أكاديمية نايف العربية للعلوم الأمنية. سـليمـان، عبــ الله العقيـل (1433هـ). الشباب السعودي والعهـل الــعوي: دراسـة استطلوعية. مجلسة

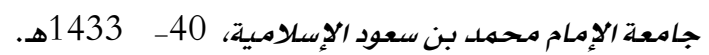
عثمـان، بـن صـالح العـامـر (1425هـ) .ثقافـة التطوع لـلى الشباب السعودي: دراسـة ميلانيـة. مديريـة التربية والتعليهم بحائل.

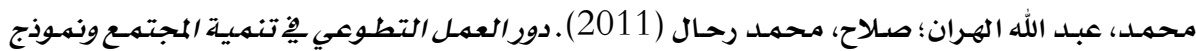
لتفعيلة. محمد، عاطف غيث (2009). قاموس علمر الاجتماع. دار المعرفة الجامعيلة. عثمان، بن صالح العامر (1425هـ) .ثقافة التطوع لدى الشباب السعودي "دراسة مىدانىة" . حائل.

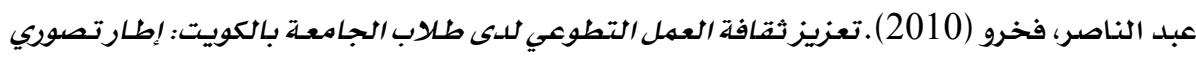
مقترح· جامعة الكويت،

تركي، بن حسن أبو العلا (2017) . إسهامات طالب الجامعة يِ دعم المبادرات التطوعية.

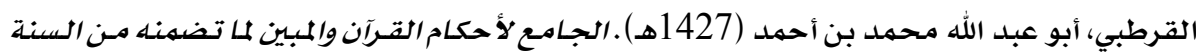
وأي الفرقان، تحقيق عبد الله التركي. مؤسسة الرسالة. 
الطبر ي، أبو جعفر محمد بن جرير (د. ت.). تفسير الطبري جامع البيان عن تأويل أي القـرآن (حققهه: محمود شاكر) . مكتبة ابن تيمية.

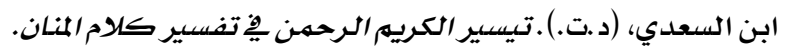

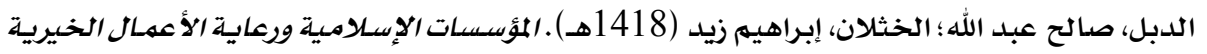

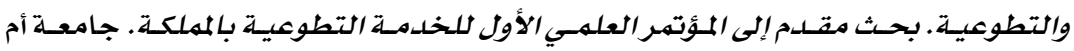

القرى، مكة المكرمـة.

فهـل، سـلطان السـلطان (2009). اتجاهـات الـشباب الجـامعي الـذكور نحـو العمـل التطـوعي. دراســة

تطبيقية يِّ جامعة الملك سعود، مجلة رسالة الخليج العربي، 5.

مصطفى، عبد القادر زيادة ( 2015). الأصـول الفلسفية للتربية، مبحث القيم. منشورات جامعة عين

شمس.

فاتن، العزازي (2014). تلدعيم العمل التطوعي داخل الجامعـات السعودية، مـلدخل استراتيجي. المجلـة

الدولية التربوية المتخصص.

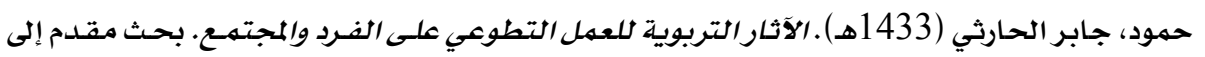

مؤتمر العمل التطوعي وآفاق المستقبل. جامعة أم القرى، مكة المكرمة.

ابن مسكويه، أحمد بن محمد الرازي (1427هـ) .تهذيب الأخلاق وتطهير الأعراق. نواف الجراح.

ثالثا: المراجع العربية مترجمة

Dhaif-Allah, S. A. (2013). The status-quo of volunteer work in the Kingdom of Saudi Arabia in [volunteer work, a vision and analyzes of Dr.: Abdulaziz Al-Melhem.

Kingdom of Saudi Arabia, Shura Council Resolution No. (123/65), dated 01/13/1432 AH, containing the draft (Voluntary work law).

Kingdom of Saudi Arabia, Royal Court, Supreme Orders, No. 19151 issued on $05 / 21 / 1434 \mathrm{AH}$.

Abdullah, A. (2000). The role of volunteer work in achieving social security and peace. Conference on Voluntary Work and Security in the Arab World. Naif Arab Academy, Riyadh.

Ministry of Education (1437 A.H.). Regulations for voluntary work in public education schools.

Muhammad, R. (1421 A.H.). Voluntary work strategy in protecting the childhood sector. Conference on Voluntary Work and Security in the Arab World. Naif Arab Academy for Security Sciences.

Suleiman, A. A. (1433 A.H.). Saudi youth and advocacy work: An Exploratory Study. Imam Muhammad bin Saud Islamic University Journal, 40-1433 AH.

Othman, S. A. (1425 A.H.). The culture of volunteering among Saudi youth: A field study. Directorate of Education in Hail. 
Muhammad, A. A.; Salah, M. R. (2011). The role of volunteer work in community development and a model for activation.

Muhammad, A. G. (2009). Dictionary of sociology. University Knowledge House.

Othman, S. A. (1425 A.H.). The culture of volunteering among Saudi youth is a "field study." Hail.

Abdel-Nasser, F. (2010). Promoting a culture of volunteer work among university students in Kuwait: A proposed conceptual framework. Kuwait University.

Turki, H. A. (2017). University student contributions in supporting volunteer initiatives.

Al-Qurtubi, A. M. A. (1427 AH). Compiling the provisions of the Qur'an and clarifying what it contains from the Sunnah and any Qur'an, verified by Abdullah al-Turki. Mission Foundation.

Al-Tabari, A. M. J. (n. d.). Tafsir al-Tabari, Jami al-Bayan, on the interpretation of the Qur'an (verified by: Mahmoud Shakir). Ibn Taymiyyah Library.

Ibn Al-Saadi, (n. d.). Facilitating the noble Rahman in the interpretation of the words of Manan.

Al-Dabal, S. A.; Al-Khathlan, I. Z. (1418 AH). Islamic institutions and sponsorship of charitable and volunteer work. Research presented to the first scientific conference of voluntary service in the Kingdom. Umm Al Qura University, Makkah.

Fahd, S. A. (2009). Attitudes of male university youth towards volunteer work. An applied study at King Saud University, The Arab Gulf Message Magazine, 5.

Mustafa, A. Z. (2015). Philosophical foundations of education, a study of values. Ain Shams University publications.

Faten, A. (2014). Supporting volunteer work within Saudi universities is a strategic approach. The International Educational Specialist Journal.

Hammoud, J. A. (1433 AH). The educational effects of volunteer work on the individual and society. Research submitted to the conference on volunteer work and future prospects. Umm Al Qura University, Makkah.

Ibn Miskawayh, A. M. A. (1427 AH). Refining morals and cleansing races. Nawaf Al Jarrah. 